\title{
Trade liberalization, industry concentration and female workers: the case of Egypt
}

\author{
Shireen AlAzzawi
}

Correspondence: salazzawi@scu.edu Department of Economics, Santa Clara University, 500 El Camino Real, Santa Clara, CA 95053, USA

\section{Introduction}

Trade theory suggests that increased openness and the subsequent specialization through trade will bring about substantial economic gains through increased job opportunities and higher relative wages to the factor of production that is in abundant supply (Hecksher-Ohlin-Samuelson model). Women, who tend to be part of the lower skilled or semi-skilled labor, the abundant factor in developing countries, should therefore gain from trade in both of these respects. Women can also gain through an additional path: increased competition through openness to international trade. A dynamic implication of the Becker (1971) model of discrimination is that increased international competition will reduce employer's ability to engage in costly discrimination, and therefore improve women's outcomes in the labor market. Alternative theories however, suggest that increased competition from trade might actually hurt those whose mobility is constrained, or have less bargaining power due to the threat of

(c) 2014 AlAzzawi; licensee Springer. This is an open access article distributed under the terms of the Creative Commons Attribution License (http://creativecommons.org/licenses/by/2.0), which permits unrestricted use, distribution, and reproduction in any medium, provided the original work is properly cited. 
unemployment, while still helping others with higher skills and better options, thereby widening wage inequalities.

These mixed theoretical predictions suggest that the effect of trade liberalization on women in the labor market depends on the nature of the liberalization process and the industrial composition of the economy being studied, and hence remains largely an empirical question. This study contributes new evidence on the relationship between increased openness to international trade and the change in earnings and employment disparities between men and women in Egypt, a key economy in the Middle East and North Africa (MENA), for which this question has not been studied before.

Egypt represents a particularly relevant setting for several reasons. In 1991, the Egyptian government initiated an economic reform and structural adjustment program (ERSAP) that aimed at transforming the heavily protected, state led economic development model that had been followed since the 1950s into a more market-based economy with greater openness to international trade. The program included three important elements that affected the labor market: increased openness to international trade, widespread privatization of State Owned Enterprises (SOEs) and reduction in government spending, which involved downsizing of employment in the government's civil service sector. Between 1991 and 2009 tariff rates were slashed by more than 50\% on average, more than half of the 314 state owned enterprises (SOEs) were privatized, and employment in the manufacturing public sector declined by more than $30 \%$. However, these reforms have gone hand in hand with marked increases in market concentration in many industries and popular discontent with the reform program. It was widely believed that a small group of businessmen benefitted from the reforms ${ }^{1}$, while the majority of the working class population was left out, with poverty and inequality increasing ${ }^{2}$.

During the same period, the status of women in the labor market in particular was deteriorating. Despite a long history of laws that purport to support "equal pay for equal work", and a public sector that was known to discriminate favorably towards women, allowing them generous maternity and child care leaves for example, gender wage inequality increased during the reform period, especially in manufacturing ${ }^{3}$. At the same time, the female labor force participation rate continuously declined (Assaad and Krafft 2013). In fact, a 2005 World Economic Forum Report on women's empowerment ranked Egypt at the bottom of the list of the 58 countries surveyed, receiving the lowest mark in all five areas of the analysis: economic participation, economic opportunity, political, health and well-being (Lopez-Claros and Zahidi 2005).

This study explores the relationship between the deteriorating status of women in the labor market in terms of both wage discrimination and employment; and level of trade liberalization and industry concentration. The paper exploits the variation in the degree of liberalization across industries, and the variation in the degree of initial concentration, using a difference-in-difference strategy, to determine the relationship between industry concentration and women's outcomes, with international trade acting as the channel of increased competition. The study finds that higher initial industry concentration, and increased import competition in initially competitive industries are associated with worse labor market outcomes for women in terms of both relative wages and employment. Increased exports in these initially competitive industries however, is associated with a lower wage gap, but also lower female employment. Results also 
indicate that opening up to increased international import competition in initially concentrated industries reduces employer's ability to discriminate against women in terms of both relative wages and employment, while increased exports in these industries is associated with higher female employment as well.

The remainder of the paper is organized as follows. Section two discusses the literature on trade liberalization and its relationship to industry concentration and gender discrimination. Section three describes women's labor market conditions, the labor market data used in the analysis, as well as the trade liberalization process. Section four describes the empirical methodology, while section five presents and discusses the results. Section six performs robustness checks, and section seven concludes and presents some policy recommendations.

\section{Literature on gender discrimination, economic reforms and trade liberalization}

The Hecksher-Ohlin-Samuelson (HOS) theory predicts that trade expansion should increase demand for the country's abundant factor which is employed intensively in the production of goods in which the country has comparative advantage. If women are relatively less skilled than men then they should gain from trade in developing countries (that are relatively more abundant in less skilled workers) through increased employment opportunities and higher relative wages. Trade openness is also an important channel for increased competition. The employer discrimination model of Gary Becker (1971) suggests that employers with market power are able to engage in discriminatory practices more than those in competitive markets earning zero economic profits. Interpreting this theory in an open economy framework implies that increased competition from international trade will also reduce employers' ability to engage in costly discrimination against women by driving down profit margins, and hence women's relative wages should rise.

If labor is not perfectly mobile however-geographically constrained for example- the short run Specific Factors model (also known as the Ricardo-Viner Model), predicts that increased trade will lead to a decline in the earnings of factors that are specific to the declining import-competing sector and an increase in the earnings of factors specific to the expanding export sector. Therefore, unskilled female workers in industries that are able to successfully raise their exports are likely to benefit from trade liberalization, while those "stuck" in import competing industries are likely to lose due to firms' intense cost-cutting efforts in the face of increased competition.

Alternative approaches, such as in Darity and Williams (1985) and Williams (1987) have also argued that an increase in trade can increase the gender wage gap, if for example, increased competition necessitates the use of discrimination as a 'tool' to cut costs. In this approach, industry characteristics such as the degree of market power, are an important determinant of wages, in addition to worker characteristics. These industry characteristics affect the bargaining power of different groups of workers. Workers with less bargaining power, due to the threat of unemployment, might be segregated into lower paying jobs, while others with higher skills and better options are paid higher wages, thereby widening wage inequalities. Competition from trade in particular, which will ultimately lead to the expansion of some industries, and contraction of others, is likely to leave those workers in the declining industries with even less options 
and hence bargaining power (Berik et al. 2004). In the case of Egypt, women in particular can be adversely affected since they are concentrated in a few sectors of economic activity, have limited geographic mobility, and have both labor market and household responsibilities that limit their labor market experience and their ability to accept many demanding, high paying job opportunities (Assaad and Arntz 2005).

More recently, Menon and Rodgers (2009) developed a model that introduced discriminatory firm behavior into a competitive market framework, and showed that the gender wage gap may not necessarily fall as a result of increased trade openness. They tested their model using data for India which also had a major trade liberalization in the early 1990s, and found that increased international exposure is associated with a larger wage gap in India's concentrated manufacturing industries.

A few other studies have also investigated the relationship between trade openness and gender discrimination, with mixed results. Black and Brainerd (2004) examined the effect of increasing competition through trade on the change in the wage gap in the USA. They found that increased trade is associated with a lower gender wage gap in previously highly concentrated industries, yet with a higher gap in industries that were already competitive. As a robustness check, they also investigate the impact on female employment, both for all female employees and for managers who are women. The relationship is insignificant for the former, but positive and significant for the latter, suggesting that increased trade is associated with having more women managers in the more concentrated industries. Kongar (2005), found that female share in low-wage production employment declined in the more trade affected, concentrated industries in the USA (no significant effect on the overall share of female employment), and argued that this decline is itself a plausible explanation for the reduction in the gender wage gap found by Black and Brainerd (2004). Artecona and Cunningham (2002) used Mexican manufacturing data between 1987 and 1993 and found that trade reform is weakly associated with a lower residual gender wage gap as predicted by Becker's theory. Berik et al. (2004) used data for Taiwan and South Korea and found that competition from foreign trade is positively associated with wage discrimination against female workers.

Reilly and Dutta (2005) investigated the effect of trade liberalization in India on the gender wage gap, without explicitly controlling for the level of industry concentration or its interaction with the trade variables. They found weak evidence that trade liberalization as measured by tariff rates and export shares is associated with a higher gender wage gap, while a higher import share is associated with a lower gap. Cross country studies (Oostendorp 2004 and Meyer 2007) have found that trade affects the gender wage gap in different ways, depending on the income level of the country.

As far as I know, El-Hamidi (2008) is the only study that examines the relationship between trade reform and gender discrimination in Egypt. She calculated the gender wage gap in sectors classified as tradable vs. non-tradable, decomposing them into explained and unexplained portions. She then used a 'before-after' approach to argue that the unexplained portion of the gender wage gap increased more in the tradable sector during the economic reform period, without explicitly controlling for the variation in trade liberalization or concentration by industry over time.

Several studies have also investigated the so-called "feminization of employment" in developing countries following trade reforms, especially increased export orientation, without controlling for industry concentration. Studies by Cagatay and Berik (1990), 
Joekes and Weston (1994), Ozler (2000) and Aguayo-Tellez, et al. (2010) and others find that trade liberalization in developing countries has been associated with an increase in women's share in employment. Studies for developed countries have had mixed results. Wood $(1991,1994)$ found little impact of trade expansion on female employment while evidence in Kucera (2001) suggests that female employment was adversely affected.

For Egypt, Assaad (2002) has shown that between 1988 and 1998, there was defeminization of both formal and informal employment, contrary to what happened in other countries, and Assaad and Krafft (2013) have found an even greater reduction in female labor force participation between 2006 and 2012, but they do not relate these findings directly to trade or industry concentration. As far as I know, the present study is the first to directly investigate the effect of trade liberalization and industry concentration on both the gender wage gap and on female employment in Egypt.

\section{Labor Market Conditions and Economic Reforms}

\subsection{Descriptive Analysis of Female Labor Market Conditions}

Table 1 presents some labor force, education and wage statistics for the labor market in Egypt over the reform period. The total labor force increased by about $60 \%$ between 1990 and 2009, however the female labor force participation rate declined by 8 percentage points between 1990 and 2002, and then started to slowly rise again until 2009, although still falling short of its 1990 level. Women have continued to face much higher unemployment rates than men. The female unemployment rate has been 3 to 4 times that of males, with roughly one out of every four females actively seeking employment not being able to find a job. Among young women (ages 15 to 24) the rate was more than $55 \%$, compared to $20 \%$ for young men in the most recent year.

Over the same period, there was a slight decrease in the relative male to female average monthly wage for all sectors, except manufacturing. In manufacturing, the male to female average monthly wage first fell between 1988 and 1998, but rose sharply to more than pre-1988 levels in 2006. This took place even though women made significant strides in bridging the education gap at all levels over this period (bottom of Table 1). This is also especially evident in Figure 1, which plots the Kernel Density function of log real hourly wage by gender and sector. Clearly, while non-manufacturing (male and female) and male manufacturing jobs' wages were rising over the period, those of females in the manufacturing sector have been left far behind, and by 2006 were lower than their pre-reform levels in real terms.

\section{Labor Market Data}

To examine the gender dimension of the labor market impacts of economic policy reforms, I use data from two nationally representative labor market sample surveys: the 1998 Egypt Labor Market Survey (ELMS 1998) and the 2006 Egypt Labor Market Panel Survey (ELMPS 2006). This allows me to track labor market conditions at important milestones during the reform process. Although the reform process officially started in 1991, a relatively small number of reforms, especially with respect to trade and privatization, had taken place by 1998. By 2006 however, a much broader and more aggressive set of reforms had been implemented, especially after a more free-market oriented cabinet took office in 2004. 
Table 1 Female labor force participation, education, and relative wages 1990 to 2009

\begin{tabular}{|c|c|c|c|c|c|c|c|}
\hline Variable & 1990 & 1995 & 1998 & 2002 & 2005 & 2006 & 2009 \\
\hline Labor force (millions) & 16.8 & 17.8 & 18.5 & 20.8 & 23.9 & 24.0 & 26.4 \\
\hline Female labor force (millions) & 4.5 & 4.1 & 3.9 & 4.3 & 5.1 & 5.3 & 6.4 \\
\hline \multicolumn{8}{|c|}{ Labor force participation rate (\% of population 15-64) } \\
\hline Female & 27.9 & 22.9 & 20.4 & 20.3 & 22.3 & 22.5 & 25.0 \\
\hline Male & 76.2 & 74.7 & 74.0 & 75.7 & 79.7 & 77.2 & 77.8 \\
\hline \multicolumn{8}{|c|}{ Unemployment by gender and age (\%) } \\
\hline Female & 17.9 & 24.1 & 19.9 & 23.9 & 25.1 & 24 & 22.9 \\
\hline Male & 5.2 & 7.6 & 5.1 & 6.3 & 7.1 & 6.8 & 5.2 \\
\hline Total & 8.6 & 11.3 & 8.2 & 10.2 & 11.2 & 10.6 & 9.4 \\
\hline \multicolumn{8}{|c|}{ Youth unemployment (ages 15 to 24) } \\
\hline Female & & & 42.8 & 40 & 62.2 & 55.2 & \\
\hline Male & & & 15.8 & 21.4 & 23.3 & 20.6 & \\
\hline \multicolumn{8}{|c|}{ Wage and salary workers (\% of those employed) } \\
\hline Female & .. & 52.9 & 60.7 & 67.9 & 50.8 & 53.7 & $47.9^{*}$ \\
\hline Male & .. & 58.1 & 59.6 & 58.4 & 62.2 & 63.7 & $61.4^{*}$ \\
\hline \multicolumn{8}{|c|}{ Ratio of male to female average monthly wage ${ }^{* *}$} \\
\hline All industries & $1.43^{*}$ & & 1.29 & & & 1.3 & \\
\hline Manufacturing & $1.47^{*}$ & & 1.25 & & & 1.59 & \\
\hline \multicolumn{8}{|l|}{ Education: } \\
\hline \multicolumn{8}{|c|}{ Literacy rate (\% of population aged $15+$ ) } \\
\hline Female &. & 44 &. &. & 59 & 58 & $64^{*}$ \\
\hline Male &. & 67 &. &. & 83 & 75 & $80^{*}$ \\
\hline \multicolumn{8}{|l|}{ Ratio of female to male (\%) } \\
\hline Primary enrollment & 84 & 88 & $91^{*}$ & 94 & 94 & 94 & 96 \\
\hline Secondary enrollment & 77 & 87 & $91^{*}$ & 93 & 95 & 95 & 96 \\
\hline Tertiary enrollment & 54 &. & .. & .. & $77^{*}$ & .. & $91^{*}$ \\
\hline
\end{tabular}

Source: World Development Indicators and World Bank Gender Statistics, 2013. *Data for the nearest available year was used. **Authors calculations based on Egypt Labor Market Survey 1988 and 1998, and ELMPS 2006.

The ELMS 1998 was carried out on a nationally-representative sample of 4,816 households. The ELMPS 2006 covered 8,349 households (Assaad and Roushdy 2006) . $^{4}$ The working sample includes all male and female workers, between the ages of 15 and 65, in wage employment in the manufacturing sector ${ }^{5}$. Real hourly wages are calculated as the sum of wages earned in the reference month from primary jobs, adjusted for average number of work days per month and average hours per day. For comparability purposes, wages of 1998 are inflated to 2006 Egyptian pounds using the consumer price index. Table 2 reports sample statistics for male and female workers separately for each year. The median real hourly wage was $1.97 \mathrm{LE}$ for males in the manufacturing sector in 1998, and 1.41 for females, giving rise to a male-female wage ratio of approximately $140 \%$ (unadjusted for worker characteristics). By 2006, this ratio had increased dramatically to $180 \%$. By contrast, the figures for other African countries' manufacturing sectors range between a $20 \%$ gap in favor of females in Senegal, and a 50\% gap in favor of men in Mauritius at the median of the distribution (Nordman and Wolff 2010).

The table also provides sample statistics showing differences between males and females in individual characteristics, education, region of residence and sector of employment. 


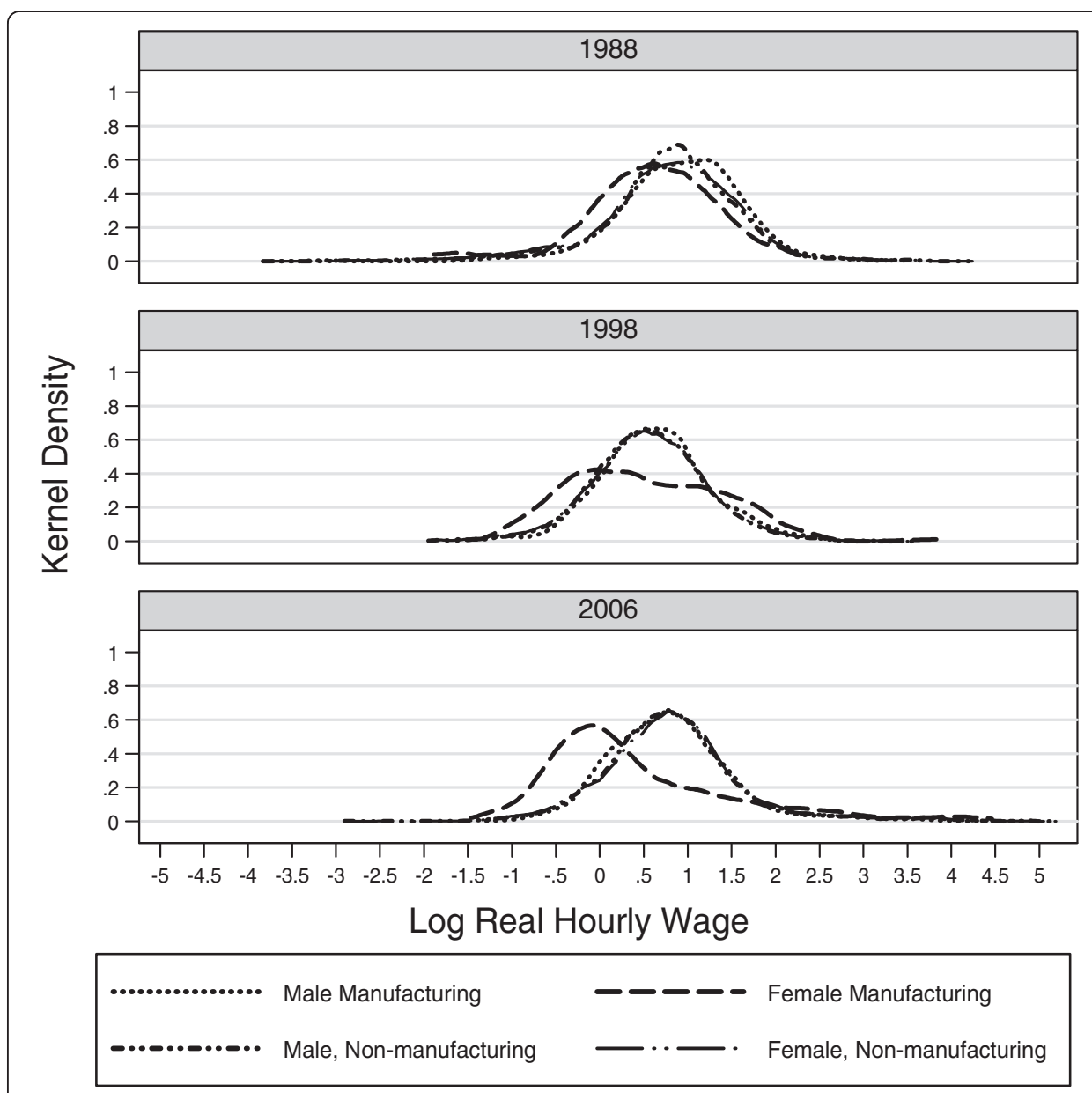

Figure 1 Wage Distribution by Sector, 1988 to 2006. Notes: Author's calculations based on data in ELMS 1988, 1998 and ELMPS 2006.

Some of the key male-female differences are that females tend to be younger than males, especially in 2006, have fewer children under 6 and to have markedly lower work experience (almost half of that of their male counterparts by 2006). Females in manufacturing tend to have higher education levels on average, with a lower share of females with a primary degree or lower in both years, and a higher share of females with a post-secondary degree and above. The majority of female manufacturing workers resided in Greater Cairo and Alexandria in both years, although rural Lower Egypt saw a significant jump by 2006.

One of the most striking findings over this period is the $50 \%$ decline in female employment in the manufacturing public sector, from $42 \%$ in 1998 to $21 \%$ in 2006. Conversely, the share of male workers only declined by $28 \%$ (from $35 \%$ to $25 \%$ ) over the same period. Privatization of more than $50 \%$ of all SOEs, that involved early retirement programs as well as layoffs of redundant workers, together with a policy of government downsizing with an effective freeze on new hires in the government sector, contributed strongly to this trend. Traditionally, many women had opted for public sector and government jobs that were more stable, less demanding and provided benefits such as extended childbearing and rearing leaves, retirement benefits, shorter hours, etc. As many of these jobs disappeared starting the late 1990s due to the economic reforms, many women found themselves in a worse situation, especially new entrants into the labor market. An 
Table 2 Summary statistics, manufacturing sector wage workers (2006 prices)

\begin{tabular}{|c|c|c|c|c|c|c|}
\hline \multirow[t]{2}{*}{ Variable } & \multicolumn{3}{|c|}{1998} & \multicolumn{3}{|c|}{2006} \\
\hline & Males & Females & Total & Males & Females & Total \\
\hline Median real hourly wage & 1.97 & 1.41 & 1.92 & 2.16 & 1.20 & 2.08 \\
\hline \multicolumn{7}{|l|}{ Individual Characteristics (means) } \\
\hline Age & 33.96 & 31.92 & 33.77 & 33.37 & 27.95 & 32.69 \\
\hline Married & 0.61 & 0.45 & 0.60 & 0.66 & 0.31 & 0.61 \\
\hline Children under 6 & 0.44 & 0.33 & 0.43 & 0.49 & 0.25 & 0.46 \\
\hline Children 6 to 14 & 0.87 & 0.85 & 0.87 & 0.46 & 0.61 & 0.48 \\
\hline Household size & 5.99 & 5.33 & 5.93 & 4.94 & 5.19 & 4.97 \\
\hline Work experience & 17.68 & 12.47 & 17.18 & 16.47 & 8.93 & 15.54 \\
\hline \multicolumn{7}{|l|}{ Education (share of workers) } \\
\hline Illiterate & 0.16 & 0.16 & 0.16 & 0.15 & 0.14 & 0.15 \\
\hline Read and write & 0.17 & 0.02 & 0.15 & 0.07 & 0.06 & 0.07 \\
\hline Primary degree & 0.17 & 0.20 & 0.17 & 0.14 & 0.10 & 0.13 \\
\hline Preparatory degree & 0.08 & 0.08 & 0.08 & 0.08 & 0.04 & 0.07 \\
\hline General secondary degree & 0.01 & 0.01 & 0.01 & 0.01 & 0.01 & 0.01 \\
\hline Vocational secondary degree & 0.28 & 0.35 & 0.29 & 0.38 & 0.45 & 0.39 \\
\hline Post-secondary degree & 0.05 & 0.07 & 0.05 & 0.06 & 0.04 & 0.06 \\
\hline University degree and above & 0.08 & 0.12 & 0.08 & 0.12 & 0.15 & 0.13 \\
\hline \multicolumn{7}{|c|}{ Region of residence (share of workers) } \\
\hline Greater Cairo & 0.27 & 0.44 & 0.29 & 0.28 & 0.32 & 0.28 \\
\hline Alexandria & 0.12 & 0.16 & 0.13 & 0.13 & 0.23 & 0.14 \\
\hline Rural upper Egypt & 0.16 & 0.07 & 0.15 & 0.14 & 0.05 & 0.13 \\
\hline Urban upper Egypt & 0.05 & 0.03 & 0.04 & 0.04 & 0.02 & 0.04 \\
\hline Rural lower Egypt & 0.28 & 0.16 & 0.27 & 0.28 & 0.27 & 0.28 \\
\hline Urban lower Egypt & 0.12 & 0.15 & 0.12 & 0.13 & 0.11 & 0.13 \\
\hline \multicolumn{7}{|l|}{ Sector (share of workers) } \\
\hline Public and government & 0.35 & 0.42 & 0.35 & 0.25 & 0.21 & 0.24 \\
\hline Private & 0.65 & 0.58 & 0.65 & 0.75 & 0.79 & 0.76 \\
\hline \multicolumn{7}{|l|}{ Observations } \\
\hline Number of observations & 758 & 85 & 843 & 1120 & 157 & 1277 \\
\hline$\%$ of workers & 90.49 & 9.51 & & 87.61 & 12.39 & \\
\hline
\end{tabular}

Notes: Author's calculations based on data in ELMS 1998 and ELMPS 2006.

important contribution of this study is to sort out the impact of trade reform from that of other changes in the economy on female relative wages and employment using direct measures of trade policy reform, trade volume as well as the degree of privatization. Note that the sample size is relatively small in both years. However, this is a nationally representative random sample, and I have used sample weights wherever relevant to ensure that the proportion of individuals and households in each sample mimics that of the true population.

To understand the impact of the reforms on females at the industry level, Table 3 provides data on the distribution of females by industry, the proportion of females in each industry out of all workers, and the industry male-female wage ratio. By 2006, over 70\% of all female manufacturing workers were concentrated in three major industries: Food 
Table 3 Distribution of females by industry, share of workers who are female in each industry and the wage gap, manufacturing sector wage workers

\begin{tabular}{|c|c|c|c|c|c|c|}
\hline \multirow[b]{2}{*}{ Industry } & \multicolumn{2}{|c|}{$\begin{array}{l}\text { Industry share } \\
\text { of total female } \\
\text { employment }\end{array}$} & \multicolumn{2}{|c|}{$\begin{array}{l}\text { Share of } \\
\text { workers in industry } \\
\text { who are female }\end{array}$} & \multicolumn{2}{|c|}{$\begin{array}{c}\text { Wage gap } \\
\text { (male wage/ } \\
\text { female wage) }\end{array}$} \\
\hline & 1998 & 2006 & 1998 & 2006 & 1998 & 2006 \\
\hline Food and beverages & 23.57 & 20 & 12.64 & 13.29 & 1.51 & 1.46 \\
\hline Tobacco & 3.49 & 0.52 & 30.87 & 8.49 & 2.43 & 0.41 \\
\hline Textiles & 10.91 & 14.84 & 8.25 & 16.54 & 1.58 & 1.79 \\
\hline Garments & 23.41 & 37.81 & 29.47 & 47.45 & 2.5 & 2 \\
\hline Leather goods & 0 & 2.86 & 0 & 17.93 & - & 1.6 \\
\hline Wood products (exc. Furniture) & 1.77 & 0.65 & 3.17 & 2.63 & 1.71 & 1.97 \\
\hline Paper & 0 & 0.98 & 0 & 6.36 & - & 3.56 \\
\hline Publishing and printing & 4.48 & 1.76 & 13.55 & 6.42 & 0.54 & 0.41 \\
\hline Coke and petroleum prod. & 8.83 & 3.99 & 10.91 & 11.47 & 1.69 & 0.39 \\
\hline Chemical prod. & 1 & 9.25 & 3.1 & 15.16 & 0.5 & 2.89 \\
\hline Rubber prod. & 0 & 0 & 0 & 0 & - & - \\
\hline Non-metallic mineral & 0 & 1.58 & 0 & 2.16 & - & 2.67 \\
\hline Basic metal & 0 & 0.48 & 0 & 2.51 & - & 0.79 \\
\hline Metallic products & 0 & 0 & 0 & 0 & - & - \\
\hline Mach. and equip. & 10.21 & 1.18 & 18.5 & 3.03 & 0.62 & 0.7 \\
\hline Office equip. and computer & 1.08 & 1.39 & 4.18 & 25.06 & 1.17 & 0.65 \\
\hline Electrical equip. (others) & 9.67 & 0.68 & 64.22 & 10.94 & 0.42 & 0.89 \\
\hline Radio, TV and com. equip. & 1.08 & 1.71 & 24.11 & 47.4 & 2.92 & 2.48 \\
\hline Medical equip. & 0 & 0 & 0 & 0 & - & - \\
\hline Motorized vehicle & 0.51 & 0.31 & 3.71 & 7.38 & 0.79 & 0.34 \\
\hline Other transport equip. & 0 & 0 & 0 & 0 & - & - \\
\hline Total & $100 \%$ & $100 \%$ & $9.51 \%$ & $12.39 \%$ & 1.3 & 1.99 \\
\hline
\end{tabular}

Notes: Author's calculations based on data in ELMS 1998 and ELMPS 2006.

and Beverages, Textiles, and Garments manufacturing, up from 60\% in 1998. Chemical Products saw the largest increase (9-fold) in employment of females over the period, and the female share in that industry also rose substantially from $3 \%$ to $15 \%$. Garment manufacturing's share of all female workers also increased substantially from $23 \%$ to $38 \%$, and the share of females in that sector almost doubled to close to $50 \%$ of all workers, the highest in all manufacturing. Other industries that witnessed large increases in female shares are Textiles, Office Equipment and Computers, and Radio, TV and Communications Equipment manufacturing. The largest decline by far was in the electrical equipment industry where women used to constitute more than $60 \%$ of all employees in 1998 , but that fell to only $11 \%$ by 2006 .

These figures can be put in perspective by looking at the relative male to female wages at the industry level, which are provided in the last column of Table 3. There are wide variations in relative wages by industry. For over half of the manufacturing industries in the sample, the unadjusted wage gap between men and women was at or above $50 \%$ in one or both of the years under consideration. The wage ratio is also quite high in the three largest female employers, ranging between 1.46 in Food and Beverages, to 2.0 in Garments in 2006. The gender wage gap widened over time in industries such as Chemical Products (increased 
by more than 5 fold-this is the same industry that witnessed a nine-fold increase in its share of female employment), Electrical Equipment, Machinery and Equipment, Textiles and Wood Products, while it declined in some notable female employers, such as Garments, and Coke and Petroleum manufacturing.

\subsection{Egypt's Trade Liberalization Program}

Like many developing countries Egypt followed a policy of state-led, import substitution industrialization in the 1960s and early 1970s. Faced with a debt crisis in 1982, Egypt was one of the first countries in the region to shift towards a more outward oriented trade policy. ERSAP involved several important trade liberalization steps. Between 1991 and 2009 , average tariff rates were slashed by more than $50 \%$. Egypt became a WTO member in 1995, and signed or ratified several trade agreements starting in the late 1990s. These include the Common Market for Eastern and Southern Africa (COMESA) and the PanArab Free Trade Area (PAFTA) in1998; the Trade and Investment Framework Agreement (TIFA) with the USA in 1999; the Egypt- EU Partnership, the AGADIR (with Jordan, Tunisia and Morocco) and Qualified Industrial Zones (QIZ) (between Egypt, Israel and the USA) Agreements in 2004; a free trade agreement with Turkey in 2005; and the Egypt-EFTA Agreement in 2007.

The trade liberalization program was accelerated in 2004. The number of tariff bands was reduced, all customs service fees and charges on imports were eliminated, and tariff rates were further reduced, resulting in a decline in the simple average MFN tariff rate from 22\% in 1998 to $13.3 \%$ in 2005 in the Manufacturing Sector (WDI 2013). According to the World Bank, by 2005, Egypt's average tariff rate was low by world standards, lower than the rates in 60 percent of the countries in the world. Furthermore, Egypt's progress in trade liberalization between 2000 and 2004 was among the strongest in the world (World Bank 2005). These reforms clearly paid off as can be seen from the substantial increase in both exports and imports after 2004 in Figure 2.

\section{Trade Reform and Gender Discrimination: Empirical Methodology}

A two-step process is used to study the impact of increased international competition on the gender wage gap in Egypt. First, Mincer earnings equations are estimated to explain

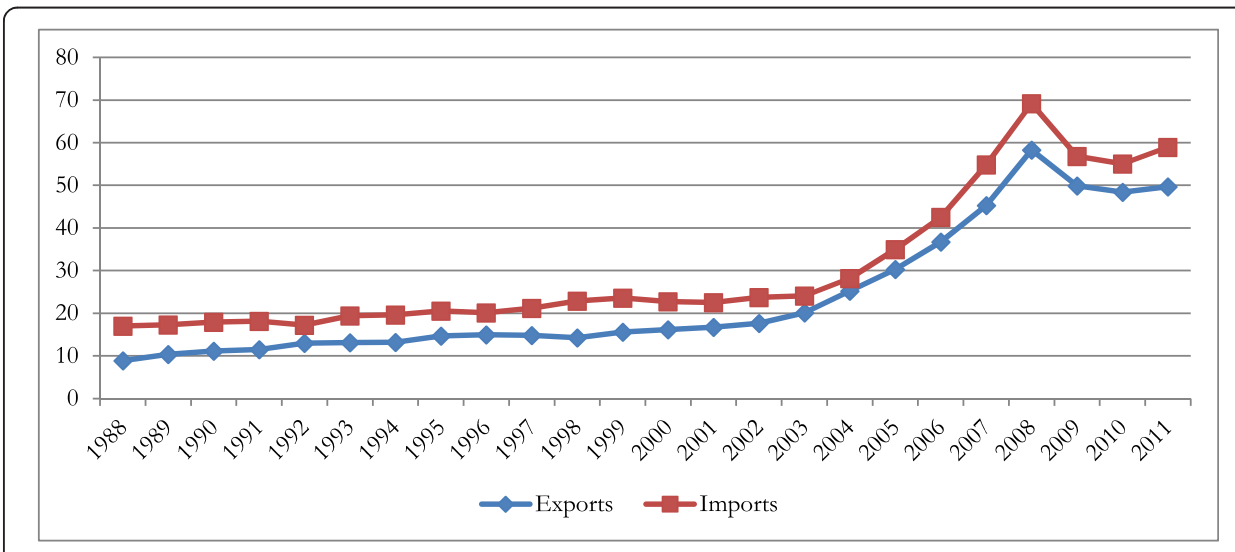

Figure 2 Exports and Imports 1988-2011, constant 2000 US\$. Source: World Development Indicators, 2011. 
the log wages of men and women. The difference between the average male and female log wages in each industry is then decomposed into a portion due to observable characteristics and a residual commonly referred to as the unexplained or discrimination component of the gender wage gap. Second, this residual wage gap is used as the dependent variable in regressions that control for changes over time in industry concentration and exposure to trade openness.

The impact of trade liberalization on the gender wage gap cannot be adequately understood without examining how female employment has also been affected. If increased trade is associated with a rising gender wage gap for example, this might be less of a social concern if at the same time trade is associated with expanded job opportunities for women, since many will argue that some job is better than none at all. At the same time a result that implies that trade is associated with a lower gap, would have to be combined with evidence on how trade simultaneously affected employment. The wage gap might have fallen simply as a result of the disproportionate layoff of the lowest wage women workers, and in that case it would be hard to argue for its beneficial impact.

\subsection{Industry Specific Gender Wage Differentials}

The standard Oaxaca-Blinder procedure can help us to understand the extent to which the overall wage gap between men and women can be explained by differences in observed productivity characteristics such as education and experience (Oaxaca 1973; Blinder 1973). The log of real hourly wage is regressed on a set of individual productivity characteristics, region of residence, and the industry of employment. I estimate separate male and female wage equations of the form:

$$
\begin{aligned}
& \ln w_{m i}=\alpha_{m}+\boldsymbol{x}_{\boldsymbol{m} i}^{\prime} \beta_{m}+\boldsymbol{d}_{\boldsymbol{m i}}^{\prime} \delta_{m}+u_{m i} \\
& \ln w_{f i}=\alpha_{f}+\boldsymbol{x}_{\boldsymbol{f} i}^{\prime} \beta_{f}+\boldsymbol{d}_{\boldsymbol{f} \boldsymbol{i}}^{\prime} \delta_{f}+u_{f i}
\end{aligned}
$$

where the subscripts $m$ and $f$ denote male and female respectively, $i$ denotes individual $i$, $w$ is the hourly wage, $\boldsymbol{x}$ is an nx1 vector of observable characteristics of individual $i$ and includes experience (measured as survey year minus year worker entered the labor force) and its square, as well as binary variables for highest level of education attained, sector of employment, and region of residence. $\boldsymbol{d}$ is a (k-1)x1 vector of industry dummies, where $d_{i k}$ equals 1 if the $i^{\text {th }}$ worker is employed in the $k^{t h}$ of $K$ industries, and zero otherwise. $u_{i}$ is the usual i.i.d, zero mean regression error with constant variance. $\beta$ is an $n \times 1$ vector of unknown wage equation parameters to be estimated and $\delta$ is a (k-1)x1 vector of industry effects ${ }^{6}$.

The predicted log wages for a representative male and female worker in industry $\mathrm{k}$ is then given by:

$$
\begin{aligned}
& \ln \widehat{w_{m k}}=\widehat{\alpha_{m}}+\overline{x_{m k}{ }^{\prime}} \widehat{\beta_{m}}+\widehat{\delta_{m k}} \\
& \ln \widehat{w_{f k}}=\widehat{\alpha_{f}}+\overline{x_{f k}{ }^{\prime}} \widehat{\beta_{f}}+\widehat{\delta_{f k}}
\end{aligned}
$$

where $\overline{x_{m k^{\prime}}}$ are the mean characteristics of a male worker in industry $k$ and $\overline{x_{f k}}$ are the mean characteristics of a female worker in industry $k$. The industry specific gender wage gap is given by the difference between equations (3) and (4). By adding and subtracting 
the term $\overline{x_{f k}} \widehat{\beta_{m}}$ this gender wage gap can be decomposed into explained and unexplained components as follows:

$$
\ln \widehat{w_{m k}}-\ln \widehat{w_{f k}}=\left(\widehat{\alpha_{m}}-\widehat{\alpha_{f}}\right)+\left(\widehat{\delta_{m k}}-\widehat{\delta_{f k}}\right)+\overline{x_{f k^{\prime}}}\left(\widehat{\beta_{m}}-\widehat{\beta_{f}}\right)+\left(\overline{x_{m k}}-\overline{x_{f k}}\right) \widehat{\beta_{m}}
$$

The left hand side of equation (5) is the total log-wage differential between males and females in industry $k$. The last term on the right hand side of equation (5) is the part of the wage gap that can be explained by differences in observable characteristics between male and female workers in that industry, while the first three terms give the unexplained or the residual wage gap (the part attributed to gender differences in market returns to those observable characteristics). Equation (5) assumes that the male coefficients are the nondiscriminatory returns to observable characteristics (i.e. males are the reference group). Several authors have argued that this in fact is arbitrary (see Jann (2008)), and I report results based on both the male coefficients as reference, as well as those based on a pooled regression of males and females, as suggested by Neumark (1988), as a robustness check.

There are several ways to calculate the industry specific residual gender wage gap. Fields and Wolff (1995), for example, use the first two terms of equation (5) as their measure of the industry specific residual gender wage gap. Horrace and Oaxaca (2001) showed that this method yields an unidentified gender wage gap in the sense that it is not invariant to the choice of the omitted reference group for binary variables in the wage regressions (such as region of residence, education level, sector of employment, etc.). Following their suggestion, I calculate the $k^{\text {th }}$ industry residual wage gap as:

$$
\widehat{\theta_{k}}=\left(\widehat{\alpha_{m}}-\widehat{\alpha_{f}}\right)+\left(\widehat{\delta_{m k}}-\widehat{\delta_{f k}}\right)+\overline{x_{f}^{\prime}}\left(\widehat{\beta_{m}}-\widehat{\beta_{f}}\right)
$$

where $\overline{x_{f}^{\prime}}$ is the vector of mean characteristics of all women in the sample and the industry specific gender wage gap for the omitted industry is obtained by setting $\widehat{\delta_{m 1}}=\widehat{\delta_{f 1}}=0$. Horrace and Oaxaca (2001) find that this measure does a good job of rendering the residual gender wage gap identified (invariant to the choice of reference group) since changes in the intercept $\left(\widehat{\alpha_{m}}-\widehat{\alpha_{f}}\right)$ are offset by changes in the slope parameters $\left(\widehat{\beta}_{m}-\widehat{\beta}_{f}\right)$. They also investigated the use of an alternative measure of the residual wage gap which is the sum of the first three terms on the right hand side of equation (5). While this will also be better than the Fields and Wolff (1995) estimator in terms of invariance to choice of omitted group, one shortcoming is that it varies with the mean characteristics of females in each industry. They advocate using the estimator specified in equation (6) instead as it shows how a randomly selected woman would do if she were treated the same as a man with the same characteristics, while still being invariant to choice of omitted group (Horrace and Oaxaca (2001) pp.613).

4.2 International Trade, Industry Concentration and Gender Inequality: Difference-in-Differences The main contribution of this paper is to estimate the degree to which increased industry competitiveness through international trade affects gender inequality. A change in the wage gap (female employment) can occur due to general changes in the economy, due to trade liberalization directly, or due to the impact of trade on the level of competition ${ }^{7}$. The key challenge is to sort out the latter effect. Firms in industries that are initially more concentrated face less domestic pressure to reduce costs compared to those in more competitive industries. Hence any observed change in concentrated firms' discrimination 
against women after trade liberalization can be attributed to the increased competitive pressures from international trade. I use a difference-in differences estimation methodology to identify the impact of international competition on the wage gap (female employment), exploiting the difference in pre-liberalization concentration ratios by industry, and the variation in the degree of tariff reduction or trade volume increases after liberalization, to determine the differential impact of trade reforms ${ }^{8}$.

The first differencing eliminates the time-invariant characteristics that might affect the residual wage gap or female employment. Sorting out the impact of trade is more complex, since trade has both a direct impact (as derived from the HOS theory), and an additional effect through its impact on industry competition (and how this affects discrimination as implied by Becker). To sort this out I therefore "conceptually" divide the observations into a control group and a treatment group. The control group consists of those industries that were already competitive; thus comparing the wage gap (female employment) difference between those that were trade impacted and those that were not, gives the direct impact of trade. The 'treatment' group consists of industries that were initially concentrated. Comparing the wage gap (female employment) difference between concentrated industries that were trade impacted and those that were not, gives both the direct impact of lowering trade barriers, and the indirect impact through its effect on increased competition.

This amounts to estimating the difference in inter-industry gender wage gap (female employment) between two differences: (1) trade affected and non-trade affected concentrated industries, minus that between (2) trade affected and non-trade affected competitive industries:

$$
\left[\begin{array}{lr}
\text { trade-affected } \\
\text { concentrated }
\end{array} \quad \begin{array}{cc}
\text { non-trade affected } \\
\text { concentrated }
\end{array}\right]-\left[\begin{array}{lc}
\text { trade-affected } & - \text { non-trade affected } \\
\text { competitive } & \text { competitive }
\end{array}\right]
$$

The second term captures changes in the wage gap (female employment) due to trade only, the first term captures changes due to both trade and increased competition, and thus the difference of (1) and (2) gives the impact of trade due to increased competitiveness. This can be estimated using the following regression equations for the wage gap and for female employment:

$$
\begin{aligned}
& \Delta_{t}\left(\widehat{\theta}_{k}\right)=\propto+\beta \Delta_{t} \text { Trade }_{k}+\gamma \text { Conc }_{k}+\phi\left(\Delta_{t} \text { Trade }_{k} * \text { Conc }_{k}\right) \\
& \Delta_{t}\left(\text { fem }_{-} \text {empl }_{k}\right)=\propto+\beta \Delta_{t} \text { Trade }_{k}+\gamma \text { Conc }_{k}+\phi\left(\Delta_{t} \text { Trade }_{k} * \text { Conc }_{k}\right)
\end{aligned}
$$

where $\Delta_{t}\left(\widehat{\theta}_{k}\right)$ is the first difference of the industry specific residual wage gap defined in equation (6); $\Delta_{t}\left(f e m_{-} e m p l_{k}\right)$ is the first difference in the industry specific measure of female employment, which is measured in two ways: the change in the share of female employees, and the change in the number of female employees. $\Delta_{t}$ Trade $_{k}$ is the change in the trade variable between 2006 and 1998 as measured by the change in tariffs or trade volume. According to the HOS model if unskilled labor is the abundant factor, trade liberalization lowers the gender wage gap since women, who are predominantly less skilled, will see a relative increase in their wages. In equation (8), $\beta$ should be positive when the change in tariffs is used as the trade measure since a fall in tariffs over time - 2006 tariff minus 1998 tariff that is negative-indicates trade liberalization, 
and negative for all the trade volume variables since higher volume over time is a reflection of trade liberalization. In equation (9), trade liberalization will have the opposite effect on the sign of $\beta$ as the demand for unskilled labor rises $(\beta$ should be negative when the change in tariffs is used as the trade measure, and positive for the trade volume measures). Conc $_{k}$ is a dummy variable for having an initially high industry concentration ratio, as explained below. I use the initial concentration rather than a time varying designation since trade competition itself might have altered the concentration ratio. According to theory, a higher initial concentration ratio should be associated with a higher gender wage gap (lower female employment) since employers with market power can afford to discriminate. The main coefficient of interest, $\phi$, on the interaction term, $\left(\Delta_{t} \operatorname{Trade}_{k}{ }^{*}\right.$ Conc $\left._{k}\right)$, captures the marginal effect of trade on concentrated industries relative to competitive industries. A positive coefficient on this term implies that increased competition from trade is associated with a higher wage gap (female employment) in concentrated industries, a negative coefficient implies the opposite (note that using change in tariff as the trade measure will again have the opposite implication given the way it is measured).

\subsection{Industry Data on Trade and Concentration}

Data on wages, individual characteristics and female employment were obtained from ELMS (1998) and ELMPS (2006) as described in Section 3 above. Several data sources were used to construct the trade and industry level data used in the analysis.

\subsubsection{Tariffs}

Tariff data is obtained from the World Trade Organization Tariffs Profile based on Egyptian Customs Authority data. I use applied ad-valorem tariff rates. To ensure that tariff rates for subcategories that are relatively more important in terms of total imports receive a greater weight in the constructed average industry-level tariff, a weighted average tariff was constructed using imports as the weight. The applied ad-valorem tariff rate at the Harmonized System 6 (HS-6) digit level was merged with import value data at the same level. The import-weighted tariffs were then converted to International Standard Industrial Classification (ISIC) Review 3 using the international concordance between HS-6 and ISIC Review 3 classifications at the disaggregated 4-digit level to ensure a high degree of accuracy in matching industrial subcategories. Finally, these tariff rates were weighted by the value of imports at the 4 digit industry level and the weighted average was then calculated at the 2 digit industry level. Finally, the trade policy data is linked to the labor market data at the two-digit industry level ${ }^{9}$.

Figure 3 presents data on the import weighted average tariff for 1997 and 2005, by industry. There was an average decline of $34 \%$ in all of manufacturing (from $18.6 \%$ to 12.3\%), while some industries such as Coke and Petroleum declined by almost triple that amount. Most notably, the Food and Beverages and the Textiles industries, two of the biggest employers of women, witnessed very large tariff reductions over this period.

\subsubsection{Trade Volume}

Exports and imports data are from the World Integrated Trade Solution (WITS) database. They are based on the national accounts constructed by the Central Agency for Public 


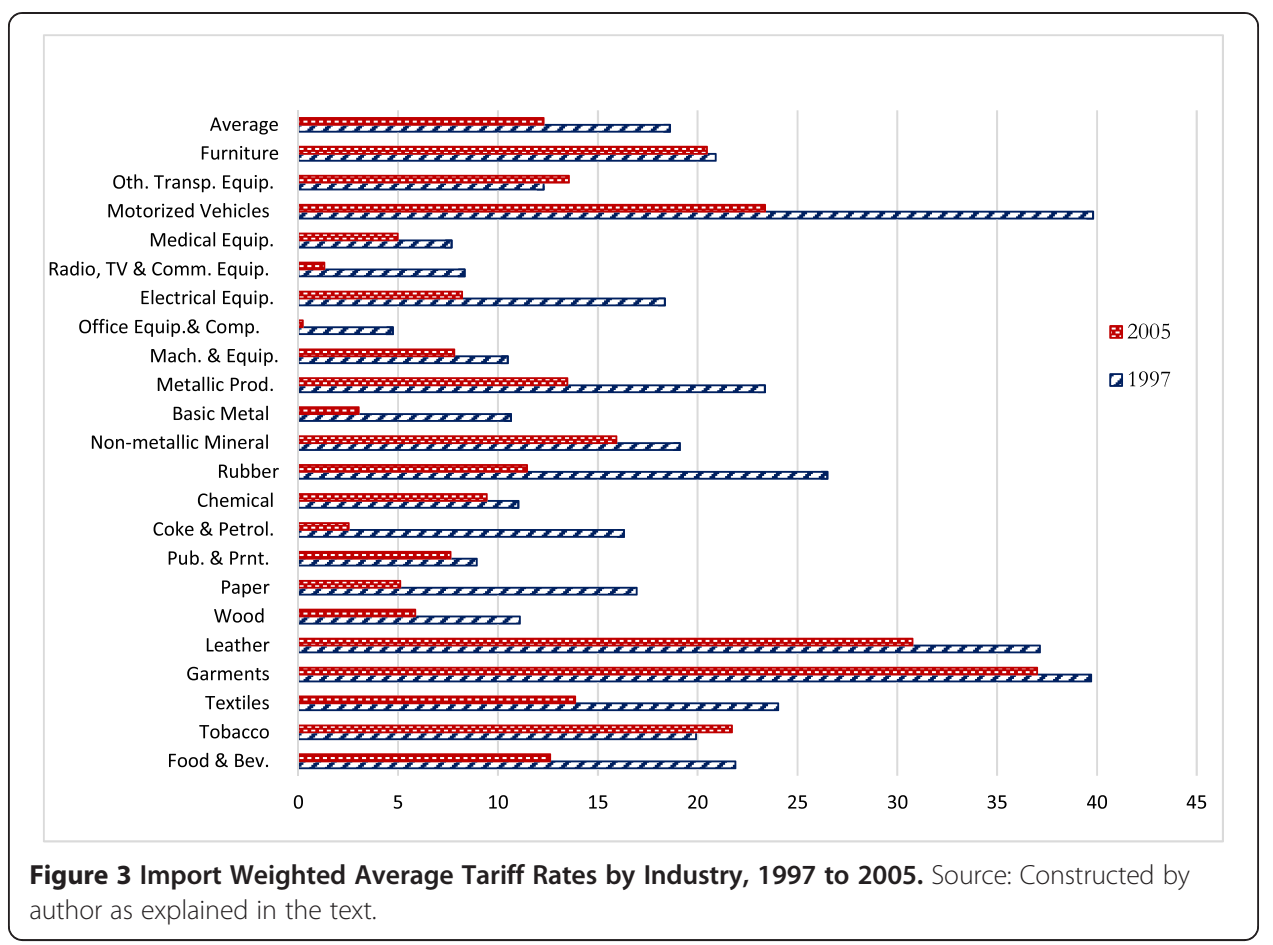

Mobilization and Statistics (CAPMAS). These variables are used to construct several indices of trade volume that will be used in the regressions. Import penetration in industry $\mathrm{k}$ is calculated as imports in industry $\mathrm{k}$ as a proportion of domestic consumption in that industry, (imports/(output + imports - exports) $)^{10}$. Export intensity is calculated as exports in industry $\mathrm{k}$ as a proportion of output in that industry, (exports/output). Trade openness is measured as the sum of imports and exports divided by total output ((imports + exports)/output).

Figures 4 and 5 present data on the import penetration and export intensity indices at the industry level. On average the import penetration index rose by $10 \%$ and the export intensity index rose by $70 \%$ over this period for all manufacturing. The largest percentage increases in import penetration were in Coke and Petroleum, Publishing and Printing, and Garments. The largest increases in export intensity were in Coke and Petroleum and Office Equipment and Computers. For the three large employers of women; Food and Beverages raised their exports by more than $250 \%$, but both Textiles and Garments Manufacturing saw declines in their exports relative to output over this period.

Much of trade today is two-way trade, where a country exports and imports the same goods. Egypt, for example, is both an exporter and an importer of products such as textiles, garments and leather goods. Relying on the import or export shares alone to determine whether an industry is a net importer or a net exporter might therefore be misleading. The established measure of the degree of intra-industry trade is the Grubel and Lloyd trade overlap index. This index is of relatively limited use for my analysis since it only provides information about the degree to which industries are "balanced" in their interactions with the rest of the world ${ }^{11}$. A simple adaptation of the Grubel-Lloyd index that uses net imports (or net exports) provides information about whether an industry is relatively more import oriented or export oriented, not only about whether its trade is balanced. It is measured as (imports-exports)/(output + imports - exports) and will be 


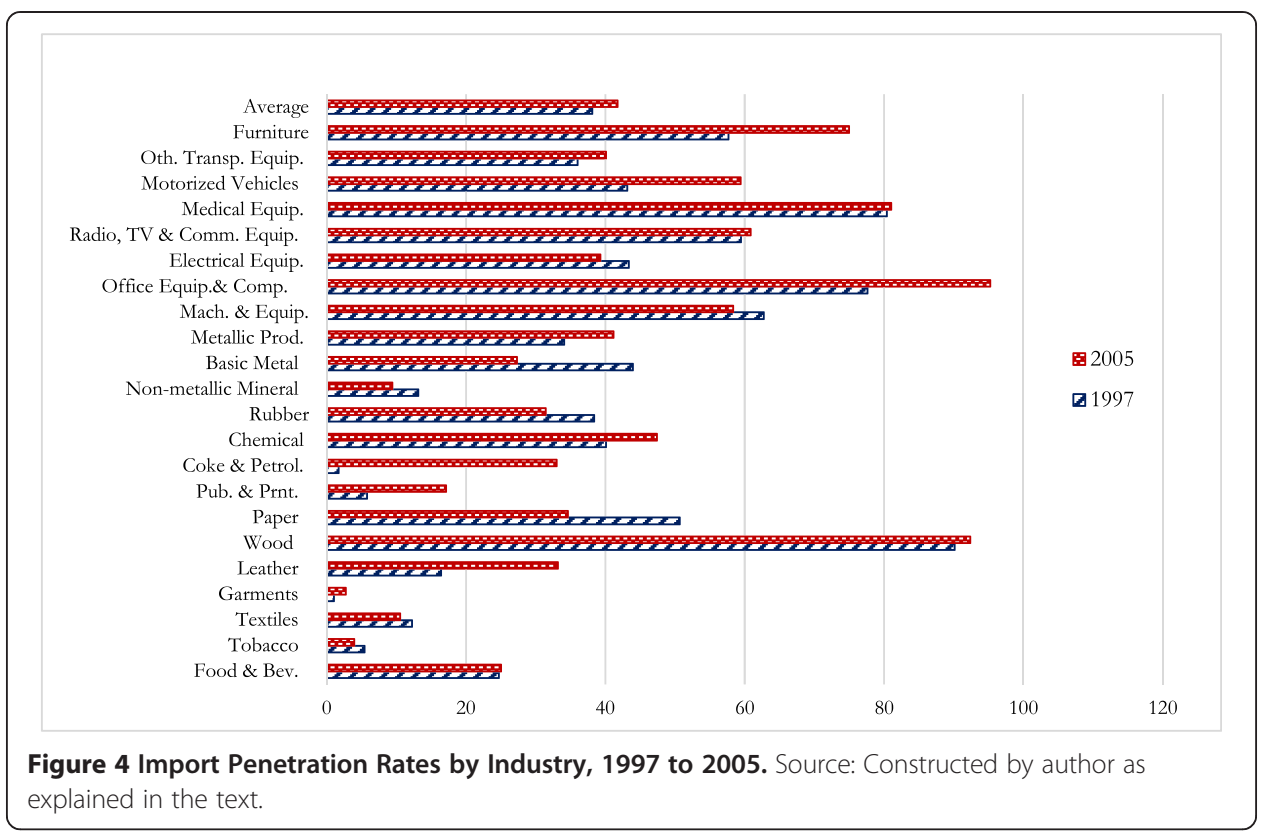

referred to as the industry penetration index. A positive number indicates that this industry faces a high degree of international competition from imports. A negative number indicates that this industry's products are able to compete successfully in international markets ${ }^{12}$. These trade-based measures could be considered endogenous, although this argument is much stronger in analyses looking at the impact on inter-industry wages. I circumvent this problem by using trade-based measures that are lagged by one year (1997 and 2005 data). Table 4 reports the Spearman rank correlation coefficients between the different changes in trade variables. The correlations are consistent with expectations, although some are quite small, reflecting the fact that while they are related, each does measure a different aspect of trade liberalization.

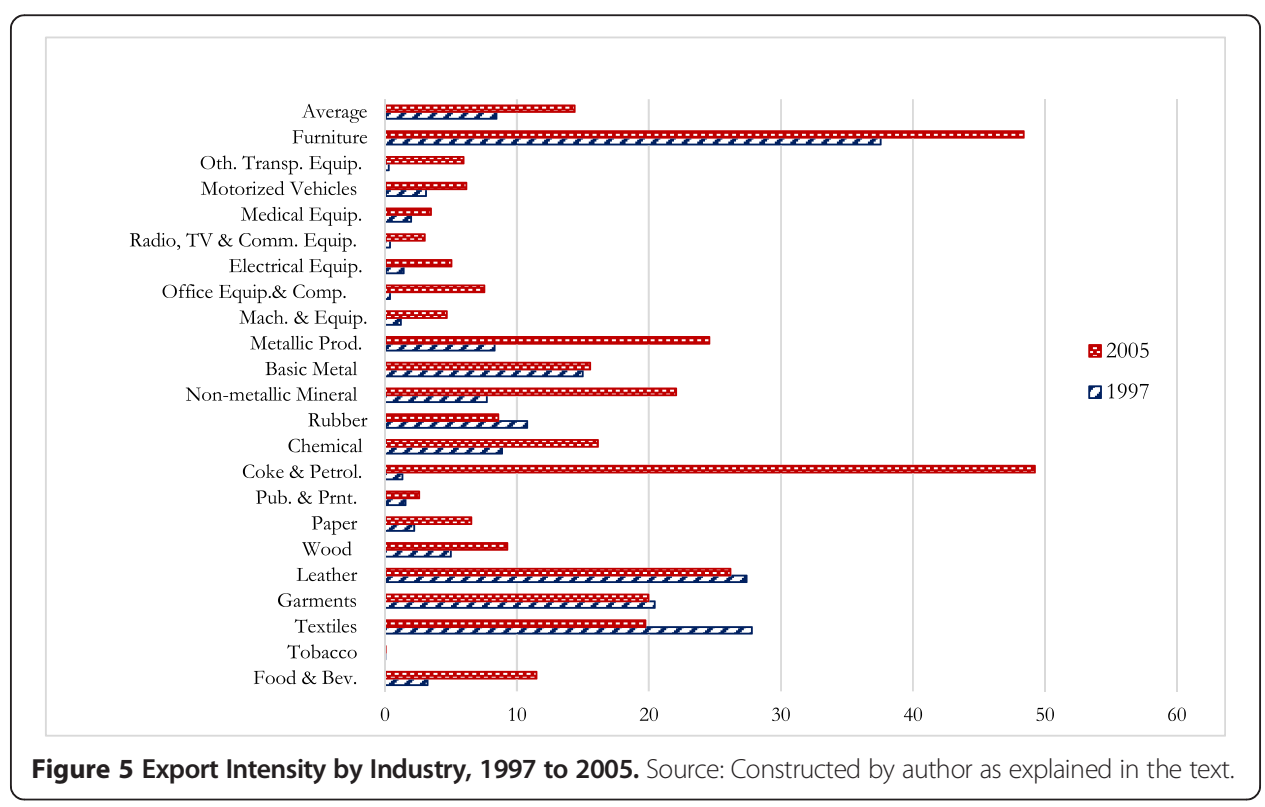


Table 4 Spearman rank correlation coefficients of trade variables

\begin{tabular}{llllll}
\hline & $\begin{array}{l}\text { Change } \\
\text { in tariff }\end{array}$ & $\begin{array}{l}\text { Change } \\
\text { in import } \\
\text { penetration }\end{array}$ & $\begin{array}{l}\text { Change } \\
\text { in export } \\
\text { intensity }\end{array}$ & $\begin{array}{l}\text { Change } \\
\text { in trade } \\
\text { openness }\end{array}$ & $\begin{array}{l}\text { Change } \\
\text { in industry } \\
\text { penetration }\end{array}$ \\
\hline Change in tariff & 1 & & & & \\
Change in import penetration & 0.1835 & 1 & 1 & & \\
Change in export intensity & 0.0265 & 0.3529 & 0.4794 & 1 & 1 \\
Change in trade openness & 0.1801 & 0.913 & -0.3224 & 0.5099 & 1 \\
Change in industry penetration & 0.3303 & 0.5889 & & & \\
\hline
\end{tabular}

\subsubsection{Industry Concentration}

There are various ways to measure industry concentration. The two most common measures in the literature are the four-firm concentration ratio and the Herfindahl Index. These measures require data on the output or sales of every firm in each of the 21 manufacturing industries under consideration for both survey years. This data was not available and I therefore used a common proxy for concentration that is based on the number of establishments in an industry divided by its output. Industry concentration is measured as (1-no. of establishments/output). A smaller number of establishments implies that the industry was more concentrated, and will thus give rise to a higher value of the index. Data on number of establishments and total output by industry were obtained from the Annual Survey of Establishments published by CAPMAS.

Figure 6 shows the concentration ratios by industry over the period, ranking the industries into "more" and "less" concentrated according to the value of the concentration ratio in 1997. I constructed a dummy variable for concentrated industries, taking the value of 1 for all those classified as "more concentrated" in 1997 in Figure 6, to be used in the regressions. Based on this designation, the coke and petroleum industry is the most concentrated (this is also true for 2005), followed closely by the office equipment and computer manufacturing industry, the motorized vehicle manufacturing industry and the tobacco industry. Notably, all but three industries witnessed increased levels of concentration over this period.

\subsubsection{Additional Industry Level Controls}

To account for other important time-varying industry-wide characteristics that might affect the gender wage gap, I include other industry characteristics in the regressions. One of the most important events taking place in the Egyptian economy since the reform program began in 1991, and more intensely in the late 1990s and early 2000s is the privatization of state owned enterprises and the downsizing of the government sector. Public sector jobs tended to offer women more equitable working conditions in general, since pay scales are set strictly according to education level and years on the job and hence women are less likely to be discriminated against. The large decline in the share of women in public sector employment discussed earlier is likely to have a strong influence on the results. Data on the number of privatized firms by industry is not available but an even better proxy from a labor market perspective is the share of workers in each industry who are private sector workers, since it captures the impact on workers directly. I therefore include the change over time in the share of workers who are in the private sector by industry as an explanatory variable in the regressions. A positive coefficient on this 


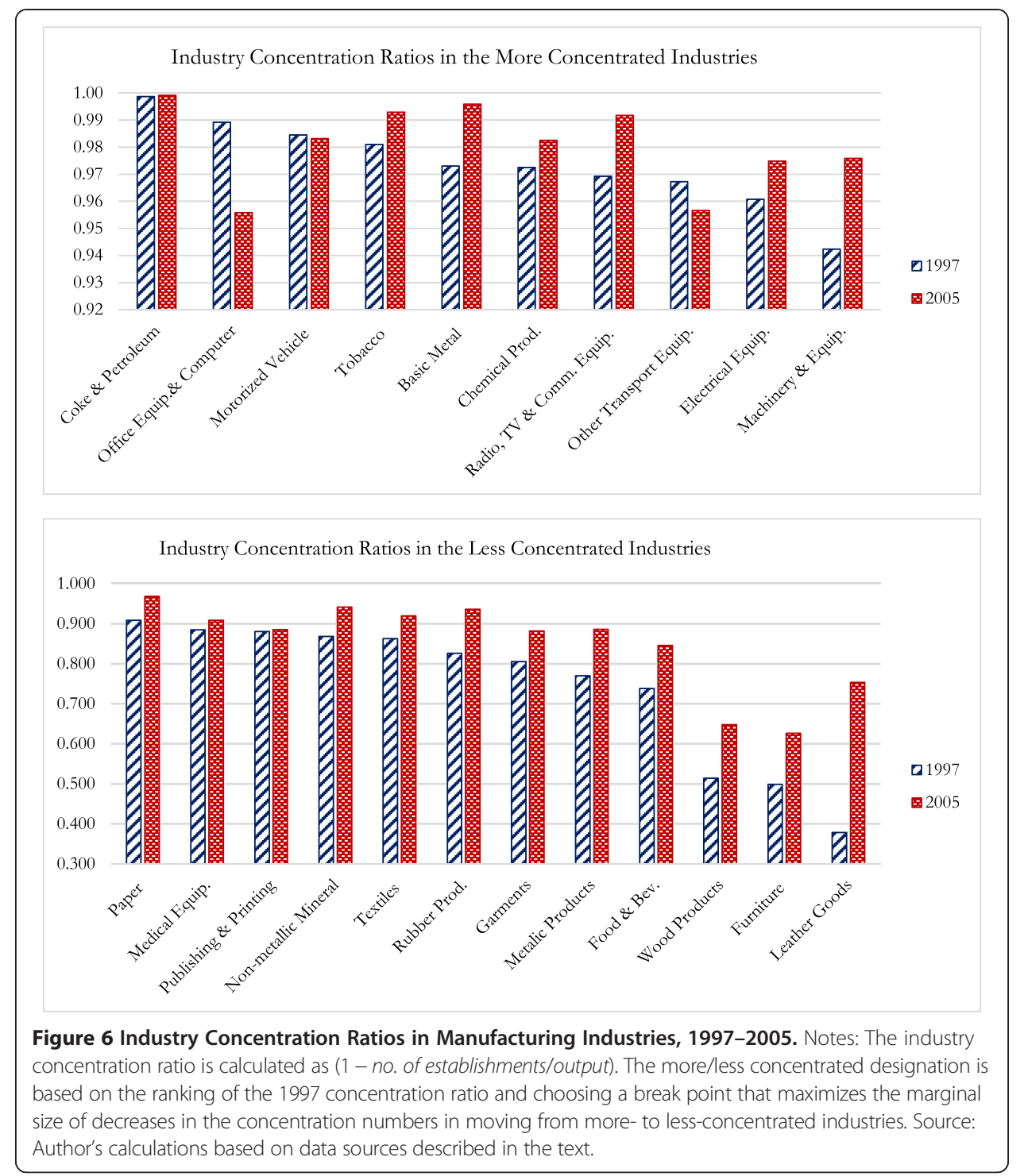

variable in equation 8 (9) implies that privatization is associated with a higher residual wage gap (female employment).

\section{Results}

\subsection{Decomposing the Gender Pay Gap}

The wage regression results are relatively typical for Egypt and other countries, and for brevity will not be discussed here. Results from the Oaxaca-Blinder decomposition are reported in Table 5 for 21 manufacturing industries. Table 5 first reports the predicted mean male and female wages followed by the gender wage gap (in logs). The results of decomposing the gap are reported next. As explained in Section 4.1, the decomposition is performed in two ways that differ in the choice of reference group. In the first two columns, coefficients from the male regressions are used as the reference, in the last two columns, coefficients from a pooled regression over all males and females in the sample are used as the reference ${ }^{13}$. 
Table 5 Oaxaca-blinder decomposition of the gender wage gaps for the manufacturing sector

\begin{tabular}{lcccc}
\hline & $\mathbf{1 9 9 8}$ & $\mathbf{2 0 0 6}$ & $\mathbf{1 9 9 8}$ & $\mathbf{2 0 0 6}$ \\
\hline Differential & & & & \\
Prediction of male log wage & $0.297^{* * *}$ & $0.792^{* * *}$ & $0.297^{* * *}$ & $0.792^{* * *}$ \\
& $(0.028)$ & $(0.027)$ & $(0.030)$ & $(0.028)$ \\
Prediction of female log wage & 0.138 & $0.391^{* * *}$ & 0.138 & $0.391^{* * *}$ \\
& $(0.098)$ & $(0.092)$ & $(0.090)$ & $(0.089)$ \\
Total male-female wage gap (in log points) & 0.159 & $0.401^{* * *}$ & $0.159^{*}$ & $0.401^{* * *}$ \\
& $(0.102)$ & $(0.095)$ & $(0.094)$ & $(0.093)$ \\
Decomposition & & & & \\
Explained & $0.109^{*}$ & $0.181^{* * *}$ & $0.125^{*}$ & $0.209^{* * *}$ \\
& $(0.066)$ & $(0.054)$ & $(0.072)$ & $(0.055)$ \\
Unexplained & 0.050 & $0.219^{* *}$ & 0.034 & $0.192^{* *}$ \\
& $(0.083)$ & $(0.093)$ & $(0.068)$ & $(0.089)$ \\
\% Gap unexplained & $31 \%$ & $55 \%$ & $21 \%$ & $48 \%$ \\
Observations & 577 & 950 & 577 & 950 \\
\hline
\end{tabular}

Notes: Standard errors in parentheses. ${ }^{* * *} p<0.01,{ }^{* *} p<0.05,{ }^{*} p<0.1$. These decompositions are calculated using the 'Oaxaca' command in Stata, developed by Ben Jann (2008). The decompositions in the first two columns are based on using coefficients from the male regressions as the reference; while those in the last two columns are based on using coefficients from a pooled regression over males and females in the sample, and including a group indicator as an additional variable, as recommended by Jann (2008).

The male-female wage gap was 0.159 log points in 1998 (borderline significant at the $10 \%$ level), and increased to $0.401 \log$ points in 2006 (significant at the 1\% level). The wage gap can be converted to a ratio of geometric means by exponentiation, giving a male to female wage ratio of 117 percent in 1998 and 150 percent in 2006. Decomposing this difference into explained and unexplained portions, the results indicate that in 1998, 69\% (79\% using pooled regression coefficients) of the wage gap was due to differences in worker characteristics. Conversely, in 2006, $55 \%$ of the wage gap ( $48 \%$ using pooled regression coefficients) was accounted for by unexplained factors. This term quantifies the change in women's wages if one was to apply the men's coefficients (coefficients from a pooled regression) to the women's characteristics, and indicates that women would in fact have seen their wages rise considerably if they were treated the same way as the reference group ${ }^{14}$. While the magnitudes of the explained and unexplained portions change somewhat depending on reference group, it is interesting to note that the unexplained gender wage gap rises dramatically between 1998 and 2006 regardless, rising 4.4 or 5.6 - fold, depending on reference group.

\subsection{Inter-Industry Gender Pay Gap and Trade Liberalization}

The results of estimating the difference-in-differences model in equation (8) are reported in Table $6^{15}$. The specifications differ according to the measure of trade used. Specification (1) uses the import-weighted average tariff as the trade policy variable, specification (2) uses the import penetration rate as the trade volume measure, specification (3) uses export intensity, specification (4) uses the trade openness index, and specification (5) uses the industry penetration index. Concentration is measured as the dummy variable for being more concentrated according to the division in Figure $6^{16}$. To account for general 
Table 6 Trade liberalization, industry concentration and the inter industry gender wage gap

\begin{tabular}{lccccc}
\hline Independent variables & $\begin{array}{c}(\mathbf{1}) \\
\text { Tariff }\end{array}$ & $\begin{array}{c}(\mathbf{2}) \\
\text { Import } \\
\text { penetration }\end{array}$ & $\begin{array}{c}(\mathbf{3}) \\
\text { Export } \\
\text { share }\end{array}$ & $\begin{array}{c}(\mathbf{4}) \\
\text { Trade } \\
\text { openness index }\end{array}$ & $\begin{array}{c}\mathbf{( 5 )} \\
\text { Industry } \\
\text { penetration }\end{array}$ \\
\hline Conc. X Change in trade & 0.274 & $-1.077^{* *}$ & 0.101 & 0.072 & -0.417 \\
Change in trade & $(0.419)$ & $(0.427)$ & $(0.136)$ & $(0.377)$ & $(0.245)$ \\
& 0.112 & $0.728^{*}$ & $-0.438^{* * *}$ & 0.074 & $0.894^{* * *}$ \\
Conc. & $(0.364)$ & $(0.388)$ & $(0.124)$ & $(0.309)$ & $(0.233)$ \\
Change in share of private sector workers & $1.034^{* *}$ & $0.881^{*}$ & $0.993^{* * *}$ & 1.454 & $1.341^{* * *}$ \\
& 0.403 & $0.492^{*}$ & $0.815^{* *}$ & 0.508 & $0.883^{* * *}$ \\
Constant & $(0.429)$ & $(0.487)$ & $(0.285)$ & $(0.832)$ & $(0.342)$ \\
& -0.001 & 0.101 & -0.173 & 0.036 & $-0.233^{*}$ \\
Observations & $(0.208)$ & $(0.142)$ & $(0.215)$ & $(0.173)$ & $(0.113)$ \\
R-squared & 14 & 14 & 14 & 14 & 14 \\
\hline
\end{tabular}

Notes: The dependent variable for all specifications is the change in the residual inter industry gender wage gap. Conc. is the dummy for being more concentrated in 1998 as explained in the text. The change in share of private sector workers reflects the difference between 2006 and 1998 in the share of workers in the industry who worked in private sector companies. Trade variables are standardized to a mean of zero and variance of 1 for ease of interpretation. In column (1) change in trade is the change in tariff level; in ( 2$)$ it is the change in import share of domestic consumption $M /(Q+M-X)$; in (3) it is the change in export share of domestic output $X / Q$; in (4) it is the change in trade openness index $(M+X) / Q$; in (5) it is the change in industry penetration index $(M-X) /(Q+M-X)$. Robust Standard errors in parentheses. ${ }^{* * *} p<0.01$, ${ }^{* *} \mathrm{p}<0.05$, ${ }^{*} \mathrm{p}<0.1$. Standard Errors adjusted for 14 clusters in the manufacturing industries.

forms of heteroskedasticity and serial correlation in the error term, in particular intragroup correlation for workers within the same industry, I compute robust (Huber-White) standard errors clustered by industry.

The main coefficients of interest are those on the interaction term Conc. X Change in Trade, together with those on the Change in Trade variable. These two capture the difference between the trade-affected concentrated and the trade-affected competitive industries. The Change in Trade variable was precisely estimated at conventional levels in specifications (2), (3) and (5), where trade is measured by import penetration, export intensity and the industry penetration index, respectively, while the interaction term was precisely estimated in specification (2) only. The trade variables are standardized to a mean of zero and variance of one for ease of interpretation.

The results from specification (2) indicate that initially competitive industries that faced higher competition from imports, also witnessed an increase in their residual industry gender wage gap over time. The negative and significant coefficient on the interaction term implies that increased competition from imports in the more concentrated industries was associated with a lower residual industry gender wage gap over time. The positive and significant coefficient on the concentration variable implies that higher concentration in general is associated with an increase in the gender wage gap over this period. Together, these three results suggest that while higher concentration and more intense exposure to competition from imports are both associated with an increase in the residual wage gap over time, exposure to competition from imports in initially concentrated industries is associated with a fall in this gap over time. Similar conclusions can be drawn from specification (5), where industry penetration is the trade variable. The coefficient on the interaction term is significant at the $11 \%$ level. These results support Becker's 
theory that international competition will reduce employers' ability to discriminate against women and are consistent with the findings of Black and Brainerd (2004) and Kongar (2005) for the USA, and Artecona and Cunningham (2002) for Mexico.

The negative and significant coefficient on the change in export intensity in column (3) implies that in initially competitive industries, an increase in export intensity is associated with a lower residual wage gap. The coefficient on the interaction term is positive but imprecisely estimated at conventional levels. However, note that the negative coefficient on the interaction term in specification (5), where industry penetration is the measure of increased trade (significant at the $11 \%$ level), is fully consistent with that from specification (3), where export intensity is the measure of trade, since a negative value for the industry penetration index implies the industry is relatively more export oriented as explained in Section 4.3.2. These two results suggest that increased success at exporting in competitive industries is associated with lower discrimination against women, while in concentrated industries there is weak evidence to suggest it is associated with higher gender wage gaps over time. The magnitude of the impact is quite substantial: for example a one standard deviation change in export intensity is associated with a decrease of 0.438 in the residual gender wage gap in that industry. In all specifications, the change in the share of private sector workers also proved to be an important industry level control, with the positive coefficient implying that industries that saw a rise in their share of private sector workers over this period also saw their gender wage gap increase ${ }^{17}$.

\subsection{Female Employment and Trade Liberalization}

Table 7 reports the results of estimating equation (9) using the share of female employees (in columns (1) to(5)) and number of female employees (in columns (6) to(10)) as dependent variables, respectively ${ }^{18}$. The columns differ according to the measure of trade used as in Table 6.

The negative and significant coefficient on the change in trade variables in specifications (2), (3), (4), (7) and (9), where trade is measured by import penetration, export intensity and the trade openness index, implies that increased exposure to international trade in competitive industries, whether through exports or imports, is associated with a fall in female employment as measured by both female share and number of female employees. For example, a one standard deviation increase in import penetration is associated with a 0.19 fall in the share of female employees, which is quite substantial. A one standard deviation increase in export intensity however has a smaller impact, being associated with a fall in female employment share of 0.06. In concentrated industries that were trade affected however, the opposite appears to be the case as the positive and significant coefficients on the interaction term in specifications (2), (3), (7) and (9) imply. Increased imports, exports and overall trade, are associated with an increase in female employment in the more concentrated, trade affected industries, compared with the competitive, trade affected ones. Thus while opening up to free trade might have hurt women's employment prospects in the competitive industries, in the concentrated industries it seemed to be reducing employers' ability to discriminate against women.

The analysis in these two sections has attempted to test the dynamic implications of Becker's theory of discrimination in the context of increased international trade by testing the relationship between the change in industry residual gender wage gap and female 
Table 7 Trade liberalization, industry concentration and female employment

\begin{tabular}{|c|c|c|c|c|c|c|c|c|c|c|}
\hline Independent variables & $\begin{array}{c}(1) \\
\text { Tariff }\end{array}$ & $\begin{array}{c}\text { (2) } \\
\text { Import } \\
\text { penetration }\end{array}$ & $\begin{array}{c}\text { (3) } \\
\text { Export share }\end{array}$ & $\begin{array}{c}\text { (4) } \\
\text { Trade } \\
\text { openness index }\end{array}$ & $\begin{array}{c}(5) \\
\text { Industry } \\
\text { penetration }\end{array}$ & $\begin{array}{c}\text { (6) } \\
\text { Tariff }\end{array}$ & $\begin{array}{c}\text { (7) } \\
\text { Import } \\
\text { penetration }\end{array}$ & $\begin{array}{c}(8) \\
\text { Export share }\end{array}$ & $\begin{array}{c}\text { (9) } \\
\text { Trade } \\
\text { openness index }\end{array}$ & $\begin{array}{c}(10) \\
\text { Industry } \\
\text { penetration }\end{array}$ \\
\hline \multirow[t]{2}{*}{ Conc. $X$ Change in trade } & -0.014 & $0.213^{* * *}$ & $0.098^{* *}$ & 0.099 & 0.021 & 0.056 & $7.726^{*}$ & 6.567 & $21.904^{* *}$ & 2.669 \\
\hline & $(0.120)$ & $(0.064)$ & $(0.042)$ & $(0.100)$ & $(0.118)$ & $(7.171)$ & (3.831) & $(5.933)$ & (8.934) & $(4.967)$ \\
\hline \multirow[t]{2}{*}{ Change in trade } & -0.006 & $-0.190^{* * *}$ & $-0.067^{* *}$ & $-0.128^{*}$ & -0.058 & 1.039 & $-7.339^{*}$ & -7.314 & $-19.386^{* *}$ & 0.152 \\
\hline & $(0.085)$ & $(0.051)$ & $(0.029)$ & $(0.066)$ & $(0.110)$ & $(7.050)$ & (3.589) & $(5.901)$ & $(8.748)$ & $(4.816)$ \\
\hline \multirow[t]{2}{*}{ Conc. } & -0.155 & -0.145 & -0.140 & -0.143 & -0.186 & -8.412 & -7.624 & -4.788 & -5.477 & -7.604 \\
\hline & $(0.137)$ & $(0.116)$ & $(0.127)$ & $(0.120)$ & $(0.136)$ & $(4.914)$ & $(5.846)$ & $(5.750)$ & $(4.506)$ & $(6.440)$ \\
\hline \multirow[t]{2}{*}{ Change in share of private sector workers } & -0.149 & -0.149 & -0.144 & -0.225 & -0.171 & 5.706 & 5.287 & 5.383 & 12.260 & 6.945 \\
\hline & $(0.216)$ & $(0.215)$ & $(0.187)$ & $(0.356)$ & $(0.219)$ & $(6.074)$ & $(5.929)$ & $(5.504)$ & $(7.858)$ & $(4.696)$ \\
\hline \multirow[t]{2}{*}{ Constant } & $0.071^{*}$ & 0.049 & 0.040 & 0.052 & 0.086 & $9.156^{*}$ & 8.571 & 6.107 & $6.711^{*}$ & 9.334 \\
\hline & $(0.040)$ & $(0.032)$ & $(0.048)$ & $(0.037)$ & $(0.051)$ & $(4.539)$ & $(5.300)$ & $(5.104)$ & $(3.789)$ & $(5.924)$ \\
\hline Observations & 14 & 14 & 14 & 14 & 14 & 14 & 14 & 14 & 14 & 14 \\
\hline R-squared & 0.203 & 0.262 & 0.234 & 0.226 & 0.221 & 0.270 & 0.296 & 0.320 & 0.430 & 0.301 \\
\hline
\end{tabular}

Notes: The dependent variable in specifications (1) to (5) is the change in female share of employment, in specifications (6) to (10) it is the change in the number of female employees. Conc. is the dummy for being more concentrated in 1998 as explained in the text. The change in share of private sector workers reflects the difference between 2006 and 1998 in the share of workers in the industry who worked in private secto companies. Trade variables are standardized to a mean of zero and variance of 1 for ease of interpretation. In columns (1), (6) change in trade is the change in tariff level; in (2), (7) it is the change in import share of domestic consumption $\mathrm{M} /(\mathrm{Q}+\mathrm{M}-\mathrm{X})$; in (3), (8) it is the change in export share of domestic output $\mathrm{X} / \mathrm{Q}$; in (4), (9) it is the change in trade openness index (M+X)/Q; in $(5),(10)$ it is the change in industry penetration index $(M-X) /(Q+M-X)$. Robust Standard errors in parentheses. ${ }^{* *} p<0.01,{ }^{* *} p<0.05,{ }^{*} p<0.1$. Standard Errors adjusted for 14 clusters in the manufacturing industries. 
employment on the one hand; and the change in trade on the other, explicitly accounting for industry concentration. To put the results from the wage and employment models side by side and make them easier to interpret together, I have summarized the results in Table 8. I will focus on the varying impact of import penetration and export intensity, as the other trade variables always implied similar conclusions, and separately summarize the impact on initially concentrated industries, compared to competitive ones.

The results lend support to Becker's theory. Increased competition from imports is associated with a falling gender wage gap, and with higher employment. It seems that employers' ability to discriminate in initially concentrated industries is reduced when they are made to face international competition. Rising export intensity in concentrated industries, on the other hand, had a positive but statistically insignificant effect on the residual gender wage gap. It was significantly associated with higher female employment, however. Thus, initially concentrated, exporting firms are hiring more women, but there is week evidence to suggest that many of these are relatively lower wage workers that results in an increase in the wage gap.

Increased competition from imports in competitive firms is associated with deteriorating outcomes for women: rising gender wage gap and falling female employment. Rising export intensity in competitive industries, on the other hand, is associated with a decline in the residual gender wage gap over this period, but this came at the expense of lower female employment. The wage and employment results together suggest that the reduction in the gender wage gap in exporting industries might be a result of the lower female employment, if for example, employers are laying off those with the lowest skills and therefore lowest wages to be able to remain competitive in the face of fierce international competition in export markets. If exporting requires higher quality production to be competitive internationally, the lower average female experience levels in 2006 (Table 2) might thus make them less desirable to employers when there are scores of men available for employment as suggested by the high unemployment rate, especially for youth. The fall in the residual wage gap in competitive industries associated with increased exports supports the HOS hypothesis: if women are the abundant factor then increased trade should increase their real returns and hence results in the lower gender wage gap. However, the fall in female employment associated with rising exports and imports, and the rise in the gender wage gap associated with imports in competitive industries contradict the HOS hypothesis. They are more consistent with the Specific Factors (Ricardo-Viner) trade model $^{19}$.

\section{Robustness Checks}

The estimation approach followed in this paper implicitly assumes that reductions in industry protection levels and increases in trade volume levels were randomly distributed and exogenous to the inter-industry gender wage gap (female employment). The exogeneity

Table 8 Summary of wage and employment results

\begin{tabular}{lcccrr} 
& \multicolumn{2}{c}{ Residual gender wage gap } & & \multicolumn{2}{c}{ Female employment } \\
\cline { 2 - 3 } & Concentrated & Competitive & & Concentrated & Competitive \\
\hline Import penetration & Fall & Rise & Rise & Fall \\
Export intensity & Rise (insignificant) & Fall & & Rise & Fall \\
\hline
\end{tabular}


assumption is stronger than if the dependent variable was industry wage rates. Black and Brainerd (2004) cite evidence to support this assumption and also suggest a simple test of exogeneity. They argue that if exogeneity does not hold we would expect industries with a higher gender wage gap (female employment) at the beginning of the period to be more vulnerable to trade, all else equal. I performed a similar test for the relationship between the residual industry gender wage gap (female employment) in 1998 and the change in tariff levels, import penetration index and export intensity over the period 1998 to 2006. The correlation coefficients were $-0.19,0.08$ and 0.10 (-0.01, 0.02 and 0.06 for employment), respectively, suggesting little correlation between the residual wage gap (employment) at the beginning of the period and changes in the trade measures. This test is by no means definitive, and that is why I have used five different measures of trade and the difference in difference methodology, with the results from the different specifications, in both the gender wage gap and employment models, pointing to similar conclusions.

Over the last two decades skill biased technological change has provided one of the most popular explanations in the literature for the observed trend of rising wage inequality, especially in the gender and racial context ${ }^{20}$. Since women are disproportionately low-skilled in most developing countries, technological changes will cause a decline in demand for female workers and worsen wage inequality, regardless of trade liberalization. Ozler (2000), for example in a plant- level study for Turkey, found that women's employment in manufacturing increased with exports; however, among plants with high female employment shares, investment in machinery and equipment leads to a decline in the relative employment of women. Thus employment gains for women following trade liberalization might be reversed as a consequence of technological change.

To ensure that skill-biased technological change is not driving the results in Section 5, as a robustness check, I estimated equations (8) and (9) adding the change in skill intensity as an additional industry level control. I constructed two measures of skill intensity: the change in the ratio of skilled to unskilled workers, where a skilled worker is defined either as one with a secondary degree or above (secondary degrees include vocational, high school, and post-secondary (two years after higher school) degrees); or one with a university degree or above. Table 9 reports a subsample of these results for wage gap and female share of employment regressions where trade is measured by export intensity. Those for other trade variables were not statistically significant except for the wage gap regressions where a skilled worker is defined as one with university degree and higher (in the latter case the coefficients on our main variables of interest, Conc. X Change in Trade and Change in Trade, were of the same sign and similar magnitudes as those in Table 9 and are not shown for brevity).

First, the signs and magnitudes of the coefficients on our main variables of interest, Conc. X Change in Trade and Change in Trade are almost identical to those in Tables 6 and 7. The impact of skill depends on the way it is defined. When skill is defined as having a secondary degree or above, results in specification (1) imply that an increase in the ratio of skilled to unskilled workers in an industry is associated with an increase in the gender wage gap over time. The coefficient is negative but statistically insignificant in the female share of employment regression in specification (3). When skill is defined as having a university degree or above, however results in specifications (2) and (4) imply that an increase in the ratio of skilled to unskilled workers in an industry is associated with a decrease in the gender wage gap, and an increase in female employment share over time, 
Table 9 Skill-biased technological change, gender wage gap and female employment

\begin{tabular}{|c|c|c|c|c|}
\hline \multirow{3}{*}{$\begin{array}{l}\text { Dependent variable } \\
\text { "Skilled" defined as }\end{array}$} & (1) & (2) & (3) & (4) \\
\hline & \multicolumn{2}{|c|}{$\begin{array}{l}\text { Change in residual } \\
\text { gender wage gap }\end{array}$} & \multicolumn{2}{|c|}{$\begin{array}{c}\text { Change in female } \\
\text { share of employment }\end{array}$} \\
\hline & $\begin{array}{c}\text { Secondary } \\
\text { degree and above }\end{array}$ & $\begin{array}{c}\text { University } \\
\text { degree and above }\end{array}$ & $\begin{array}{c}\text { Secondary } \\
\text { degree and above }\end{array}$ & $\begin{array}{c}\text { University } \\
\text { degree and above }\end{array}$ \\
\hline \multirow{2}{*}{$\begin{array}{l}\text { Conc. } X \text { Change in } \\
\text { Export Share }\end{array}$} & 0.022 & 0.072 & $0.108^{* *}$ & $0.106^{*}$ \\
\hline & $(0.187)$ & $(0.249)$ & $(0.043)$ & $(0.049)$ \\
\hline \multirow[t]{2}{*}{ Change in Export Share } & $-0.408^{* *}$ & -0.408 & $-0.071^{* *}$ & $-0.075^{*}$ \\
\hline & $(0.172)$ & $(0.244)$ & $(0.029)$ & $(0.038)$ \\
\hline \multirow[t]{2}{*}{ Conc. } & $0.648^{* *}$ & $0.627^{* *}$ & -0.119 & -0.087 \\
\hline & $(0.273)$ & $(0.275)$ & $(0.156)$ & $(0.136)$ \\
\hline \multirow{2}{*}{$\begin{array}{l}\text { Change in share of } \\
\text { private sector workers }\end{array}$} & $0.773^{* *}$ & $0.807^{* * *}$ & -0.116 & -0.091 \\
\hline & $(0.329)$ & $(0.213)$ & $(0.234)$ & $(0.191)$ \\
\hline \multirow{2}{*}{$\begin{array}{l}\text { Change in share of skilled } \\
\text { to unskilled workers }\end{array}$} & $0.053^{* *}$ & $-0.161^{* * *}$ & -0.007 & $0.045^{*}$ \\
\hline & $(0.023)$ & $(0.034)$ & $(0.012)$ & $(0.022)$ \\
\hline \multirow[t]{2}{*}{ Constant } & -0.096 & -0.002 & 0.030 & -0.008 \\
\hline & $(0.163)$ & $(0.225)$ & $(0.045)$ & $(0.053)$ \\
\hline Observations & 14 & 14 & 14 & 14 \\
\hline R-squared & 0.784 & 0.797 & 0.249 & 0.317 \\
\hline
\end{tabular}

Notes: The dependent variable in specifications (1) and (2) is the change in the residual inter industry gender wage gap; in specifications (3) and (4) it is the change in female share of employment. Conc. is the dummy for being more concentrated in 1998 as explained in the text. The change in share of private sector workers reflects the difference between 2006 and 1998 in the share of workers in the industry who worked in private sector companies. The change in share of skilled to unskilled workers is measured as the ratio of those with a secondary degree and above to those with less in specifications (1) and (3); and the ratio of those with a university degree and above to those with less in specifications (2) and (4). Export share is standardized to a mean of zero and variance of 1 for ease of interpretation. Robust standard errors in parentheses. ${ }^{* *} \mathrm{p}<0.01$, ${ }^{* *} \mathrm{p}<0.05$, ${ }^{*} \mathrm{p}<0.1$. Standard Errors adjusted for 14 clusters in the manufacturing industries.

respectively. These results suggest that industries that utilized the more advanced skillsthose acquired through a university degree and above-saw an improvement in women's labor market outcomes over this period while those that utilized mid-level skills saw a deterioration in women's labor market outcomes. These results also reinforce the explanation at the end of the previous section for competitive industries, if these industries prefer the types of skills acquired through secondary degrees.

\section{Conclusion and Policy Implications}

Trade openness is an important channel for increased competition, with direct implications for how women are treated in the labor market relative to men. If discrimination is costly, only employers with excess profits in concentrated industries will be able to "afford it". A dynamic implication of the work of Gary Becker (1971) is that trade openness, being a channel for increased competition, would drive down profit margins, and decrease the ability of employers to discriminate against women. Others, such as Darity and Williams (1985) and Williams (1987) have argued that an increase in trade can increase the gender wage gap in countries where female workers have lower bargaining power and where women are segregated into lower-paying, lower-status jobs. This study has empirically tested the dynamic implications of Becker's theory, by comparing the impact of international trade on wage discrimination and on female employment in concentrated and non-concentrated industries. Performing the wage and employment analyses side by side provides a more complete picture of the impact of trade on women in the labor market. 
The results lend support to Becker's theory in that employers' ability to discriminate in initially concentrated industries is reduced when they are made to face international competition from imports. Rising export intensity in concentrated industries were also associated with higher female employment, however there is weak evidence to suggest that this came at the expense of a higher wage gap. In competitive industries, increased competition from imports is associated with deteriorating outcomes for women: rising gender wage gap and falling female employment. Rising export intensity, on the other hand, are associated with a decline in the residual gender wage gap over this period, but this came at the expense of lower female employment. This implies that whether openness leads to increased import competition, or to increased export intensity, women appear to be bearing the brunt of the competitive cost cutting measures of employers that were already competitive before trade liberalization. Skill-biased technological change was found to provide a possible explanation for these findings, if employers in exporting firms prefer skills provided by secondary education, as opposed to university and above.

The results suggest a need for stronger enforcement of Egypt's Unified Labor Law passed in 2003, which prohibits wage discrimination based on gender. Stronger versions of anti-discrimination legislation also seem to be called for, such as an equal pay act, which also prohibits discrimination at entry points into the labor market, in job titles and ranks, and in pay scales, and where the judicial system is the main enforcer of any complaints.

Another important policy recommendation that emerges from this analysis is that a stronger effort to reduce industry concentration, and to increase exports, could go a long way in improving women's prospects in the labor market, both in terms of relative wages and employment. Industry concentration in general was associated with higher gender wage gaps, and when those concentrated industries were made to face increased international competition, they had both falling wage gaps and rising female employment over this period. This suggests that stronger antitrust legislation can reduce discrimination to begin with, while opening up to trade can further reduce the ability of employers that already have market power to discriminate. Additionally, higher exports were associated with a lower residual wage gap in the non-concentrated industries. Policies that promote Egyptian exports overseas, such as production subsidies, tax exceptions and special credit lines, government provision of trade facilitation services and help with marketing, can therefore help improve women's labor market outcomes, even in the non-concentrated industries.

\section{Endnotes}

${ }^{1}$ A growing body of literature provides evidence that confirms that politically connected firms managed to make windfall gains from their connections to the ruling National Democratic Party, and that these connections allowed them to increase their size and market power, even though they were much less efficient. See for example Chekir and Diwan (2013) and El-Haddad (2013).

${ }^{2}$ The solid 5 to $7 \%$ growth between 2004 and 2008, did not trickle down to the majority of the population as evidenced by rising poverty and inequality. By the most conservative estimates, Egypt's Central Agency for Public Mobilization and Statistics (CAPMAS) calculated that poverty increased from $16.7 \%$ in $1999 / 2000$ to $25.2 \%$ in $2010 / 2011$. 
Inequality also increased over this period, with the income share of the richest decile was 8.4 times that of the poorest decile; rising from a ratio of 6.2 in 1999/2000. (CAPMAS 2012 and World Bank 2007). This contributed to widespread discontent with the economic reform program, which surfaced very clearly during the January $25^{\text {th }}, 2011$ revolution, where demands for "bread" and "social justice" were combined with those for "freedom" and "human dignity".

${ }^{3}$ See for example AlAzzawi (2010); El-Hamidi (2008); El-Hamidi and Said (2008); Kandil (2009 unpublished) who document an increase in the gender wage gap over this period.

${ }^{4}$ The two surveys form a panel that tracks the same individuals over time, however, not enough observations in each industry, in each year are available in both years. I therefore rely on the two cross sections of 1998 and 2006 to ensure enough observations in each industry in each year.

${ }^{5}$ Policy variables for which we have data may not adequately capture measures of protection/liberalization in other tradable sectors such as agriculture. Liberalization in the agricultural sector in particular involved a much broader set of policies aimed at eliminating government intervention in the domestic markets, such as elimination of domestic price controls, state monopolies on procurement and sales, subsides for inputs, etc. and these likely had a significant impact on workers in that sector possibly more important than that of reducing tariffs (Minot et al. 2010).

${ }^{6} \mathrm{I}$ also used a specification that calculated selectivity corrected wage equations following Heckman (1979), to account for the probability of selection into wage employment versus non-wage employment, (which includes those who are employers, self-employed or unpaid family workers).The results were very similar to those obtained here. Selectivity correction, while important in many contexts, is not without controversy. For example, it is often difficult to justify the exclusion restrictions in the selection model. Since the main conclusions of the paper are not affected, I have only reported results without correction for selection. I thank David Neumark for detailed discussions and useful suggestions on this issue.

${ }^{7}$ This exposition closely follows Artecona and Cunningham (2002).

${ }^{8}$ Note that few trade reforms had taken place by 1998 and all major trade agreements were signed/came into effect after 1998 as explained in Section 3. This is clearly evident in the fact that exports and imports barely changed between 1991 and 1998 as shown in Figure 2. The significant trade reforms only took place after 2000, and in particular 2004. It is thus appropriate to consider 1998 as the "before" year in this analysis as it is the first year for which detailed data at the industry level is available.

${ }^{9}$ I experimented with linking the trade and labor data at the three digit industry level, however more than a third of industries at this higher level of disaggregation had fewer than 5 workers.

${ }^{10} \mathrm{I}$ also constructed another measure of import penetration: imports as a share of output in industry k. Regression results using both versions of the import penetration measure were almost identical.

${ }^{11}$ See Kletzer (2001) for a discussion.

${ }^{12}$ Data on the trade volume measures 'trade openness' and 'industry penetration' described in the text are not presented by industry for brevity, but are available from the author upon request. 
${ }^{13}$ I also include a group indicator in the pooled model as an additional variable to avoid having any "residual group differences spilling over into the slope parameters of the pooled model" as recommended by Jann (2008) (pp.6).

${ }^{14}$ Even though these results are based on a relatively small sample size, the fact that the increase in the unexplained component over this period is also found in other studies that rely on the Annual Labor Market Surveys (which were not available to the author), like El-Hamidi and Said (2008) is reassuring, and suggests this smaller sample gives consistent results.

${ }^{15}$ There are 21 manufacturing industries in the dataset. Seven of those industries did not have any female employees in 1998, and four had no female employees in 2006. (see Table 3 for female employee distribution by industry). These industries are therefore eliminated from the analysis altogether.

${ }^{16}$ I also estimated the models using the initial year concentration level (a continuous variable), however, most coefficients were imprecisely estimated at conventional levels of significance, and therefore these are not shown for brevity.

${ }^{17}$ Several other time-varying industry level variables might also impact the results: the share of blue collar relative to white collar workers, the degree of unionization and the share of casual workers, among others. I have experimented with all of these in the regressions as additional explanatory variables, but none were consistently significant in estimates of models 8 and 9, and they did not affect the main coefficients of interest. I do not show these results for brevity.

${ }^{18} \mathrm{~A}$ third measure, the change in the average hours per week of female employees, was also constructed. Results were very similar and are not shown for brevity. Likewise, I estimated the model using only full time workers (defined as those who work 40 hours a week or more). The results were similar, but less precisely estimated at conventional levels of significance.

${ }^{19}$ Competitive industries that employed the bulk of females in manufacturing, namely Textiles and Garments, saw a slight decrease in their export intensity measures over this period, as well as relatively large decreases in protection. The end of the Multi-Fiber Agreement (the quota system that benefited small exporters such as Egypt and shielded them from the more competitive exports of East Asia in international markets) made it much harder to compete internationally, while domestically, ministerial decree 161 in 2004 lifted import prohibitions on most textile and clothing products. Firms in these industries might therefore have reacted to the increased competition by laying off some of the least productive/lowest paid female workers and hence the observed effects on the wage gap and employment.

${ }^{20}$ See Violante (2008) and Berman et al. (1998) for a discussion and international evidence. anonymous referee, and participants at the Middle East and North Africa Gender and Economic Symposium II at The University of Chicago, and at the IZA Workshop on Labor Markets and Labor Policy in MENA Countries for helpful comments and suggestions. Yomna Sabry helped with the data collection. This research was funded by The Gender Economic Research and Policy Analysis (GERPA) in the context of its Second Research Competition.

Responsible editor: David Neumark 
Received: 27 June 2013 Accepted: 18 July 2014

\section{Published: 29 Sep 2014}

References
Aguayo-Tellez E, Airola J, Juhn C (2010) Did Trade Liberalization Help Women? The Case of Mexico in the 1990s. In: NBER Working Papers 16195

AlAzzawi S (2010) Importing Equality? Trade Liberalization and Gender Discrimination in Egypt. Paper presented at the Middle East and North Africa Gender and Economic Symposium II at The University of Chicago, October 2010

Artecona R, Cunningham W (2002) Effects of Trade Liberalization on the Gender Gap in Mexico. In: Policy Research Report on Gender and Development, Working Paper 21. World Bank, Washington D.C

Assaad R (2002) Informalization and De-Feminization: Explaining the Unusual Pattern in Egypt. In: Paper presented at the Conference on Rethinking Labor Market Informalization: Precarious Jobs, Poverty, and Social Protection. Cornell University, Ithaca, NY, October 18-19

Assaad R, Arntz M (2005) Constrained geographical mobility and gendered labor market outcomes under structural adjustment: evidence from Egypt. World Dev 33(3):431-454

Assaad R, Krafft C (2013) The Egypt labor market panel survey: introducing the 2012 round. IZA Journal of Labor \& Development 2(8). http://www.izajold.com/content/2/1/8. doi:10.1186/2193-9020-2-8

Assaad R, Roushdy R (2006) Poverty and the Labor Market in Egypt: A Review of Developments in the 1998-2006 Period., A paper prepared for the Word Bank as a background paper for the Egypt Poverty Assessment Update

Becker G (1971) The Economics of Discrimination. University of Chicago Press, Chicago

Berik G, Rodgers Y, Zveglich J (2004) International trade and gender wage discrimination: evidence from East Asia. Rev Dev Econ 8(2):237-254

Berman E, Bound J, Machin S (1998) Implications of skill-biased technological change: international evidence. Q J Econ 113(4):1245-1279

Black SE, Brainerd E (2004) Importing equality? The impact of globalization on gender discrimination. ILR Review 57(4):540-559

Blinder AS (1973) Wage discrimination: reduced form and structural elements. J Hum Resour 8(4):436-455

Cagatay N, Berik G (1990) Transition to export-led growth in Turkey: is there feminization of employment? Rev Radic Polit Econ 22(1):115-134

CAPMAS (2012) Poverty indicators according to the Household Income, Consumption and Expenditure Survey 2010/2011"., www.capmas.gov.eg. Accessed March 10, 2013

Chekir H, Diwan I (2013) Crony Capitalism in Egypt. Center for International Development at Harvard University, Working Paper 250

Darity W, Williams R (1985) Peddlers forever? Culture, competition, and discrimination. Am Econ Rev 75(2):256-261

Egypt Labor Market Panel Survey, Economic Research Forum and the Central Agency for Public Mobilization and Statistics (CAPMAS) (2006) Egypt Labor Market Panel Survey 2006 (ELMPS06), Version 1.0 of the licensed data files, provided by the Economic Research Forum. http://www.erfdataportal.com/index.php/catalog, Accessed April 12013

Egypt Labor Market Panel Survey, Economic Research Forum and Central Agency for Public Mobilization and Statistics (1998) Egypt Labor Market Panel Survey 1998 (ELMPS 1998), Version 1.0 of the licensed data files, provided by the Economic Research Forum http://www.erfdataportal.com/index.php/catalog, Accessed April 12013

El-Hamidi F (2008) Trade Liberalization, Gender Segmentation, and Wage Discrimination: Evidence from Egypt. Economic Research Forum Working Paper No. 414

El-Hamidi F, Said M (2008) Have Economic Reforms Paid Off? Gender Occupational Inequality in the New Millennium in Egypt. Egyptian Center for Economic Studies Working Paper No. 128

Fields J, Wolff EN (1995) Interindustry wage differentials and the gender wage gap. ILR Review 49(1):105-120

Heckman J (1979) Sample selection bias as a specification error. Econometrica 47:153-161

Horrace WC, Oaxaca RL (2001) Inter-industry wage differentials and the gender wage gap: an identification problem. ILR Review 54(3):611-618

Jann B (2008) The Blinder-Oaxaca decomposition for linear regression models. The Stata Journal 8(4):453-479

Joekes S, Weston A (1994) Women and the New Trade Agenda. UNIFEM, New York

Kletzer L (2001) Job Loss from imports: Measuring the Costs. Institute for International Economics, Washington, D.C.

Kongar E (2005) Importing Equality or Exporting Jobs?: Competition and Gender Wage and Employment Differentials in U.S. Manufacturing. Department of Economics, University of Utah Working Paper No. 2005-13

Kucera D (2001) Foreign trade of manufactures and men and women's employment and earnings in Germany and Japan. Int J Appl Econ 15(2):129-149

Lopez-Claros A, Zahidi S (2005) Women's Empowerment: Measuring the Global Gender Gap. World Economic Forum, Geneva, Switzerland

Menon N, Rodgers Y (2009) International trade and the gender wage gap: new evidence from India's manufacturing sector. World Dev 37(5):965-981

Meyer L (2007) International Trade Liberalization and Gender Wage Inequality: A Cross-National Analysis 1975-1998. Women and International Development, Center for Gender in Global Context Working Paper No. 289

Minot N, Chemingui M, Thomas M, Dewina R, Orden D (2010) Trade Liberalization and Poverty in the Middle East and North Africa. Monograph, IFPRI Research

Neumark D (1988) Employers' discriminatory behavior and the estimation of wage discrimination. J Hum Resour 23:279-295

Nordman CJ, Wolff F-C (2010) Gender Differences in Pay in African Manufacturing Firms. In: Jorge Saba A, Alexandre K, Ewa F (eds) Gender Disparities in Africa's Labor Market. World Bank, Washington D.C, pp 155-192

Oaxaca R (1973) Male-female wage differentials in urban labor markets. Int J Appl Econ 14(3):693-709

Oostendorp RH (2004) "Globalization and the Gender Wage Gap", Policy Research Working Paper 3256. World Bank, Washington, D.C.

Ozler S (2000) Export orientation and female share of employment: evidence from Turkey. World Dev 28(7):1239-1248

Reilly B, Dutta PV (2005) The Gender Pay Gap and Trade Liberalization: Evidence for India. PRUS Working Paper No. 32 
Violante GL (2008) Skill-biased technical change. The New Palgrave Dictionary of Economics. In: Durlauf SN, Blume LE (eds) The New Palgrave Dictionary of Economics, Secondth edn. The New Palgrave Dictionary of Economics Online. Palgrave Macmillan. http:/www.dictionaryofeconomics.com/article?id=pde2008_S000493. doi:10.1057/9780230226203.1538

Williams R (1987) Capital, competition, and discrimination: a reconsideration of racial earnings inequality. Rev Radic Polit Econ 19(2):1-15

Wood A (1991) North-south trade and female labour in manufacturing: an asymmetry. J Dev Stud 27(2):168-189

Wood A (1994) North-south Trade, Employment, and Inequality. Oxford University Press, Oxford

World Bank (2005) Economic Development and Prospects: Oil Booms and Revenue Management. World Bank,

Washington, DC

World Bank (2007) Arab Republic of Egypt: A Poverty Assessment Update., Report No. 39885-EGT

10.1186/2193-9004-3-20

Cite this article as: AlAzzawi: Trade liberalization, industry concentration and female workers: the case of Egypt.

IZA Journal of Labor Policy 2014, 3:20

Submit your manuscript to a SpringerOpen ${ }^{\circ}$ journal and benefit from:

- Convenient online submission

- Rigorous peer review

- Immediate publication on acceptance

- Open access: articles freely available online

- High visibility within the field

- Retaining the copyright to your article

Submit your next manuscript at $\gg$ springeropen.com 